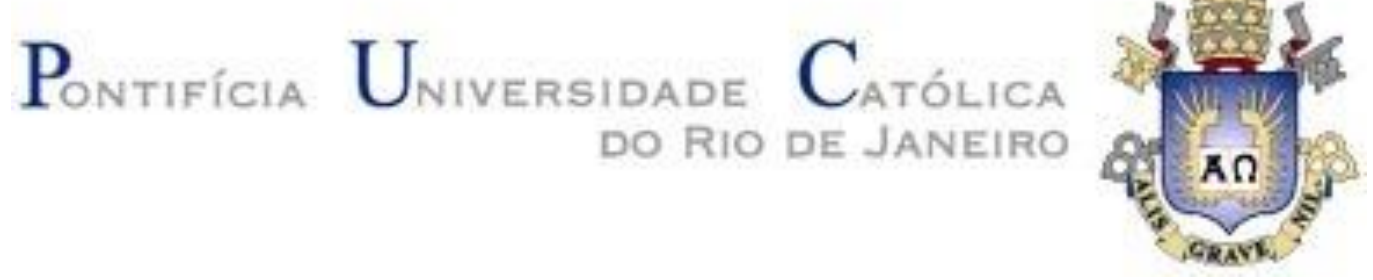

Nicole Xavier Meireles

\title{
O brincar como dispositivo clínico: intervenções com famílias
}

\section{Dissertação de Mestrado}

Dissertação apresentada como requisito parcial para a obtenção do grau de Mestre em Psicologia pelo Programa de Pós-graduação em Psicologia Clínica, do Departamento de Psicologia da PUC-Rio.

Orientadora: Silvia Maria Abu-Jamra Zornig. 


\section{Pontifícia Universidade Católica $_{\text {a }}$

Nicole Xavier Meireles

\section{O brincar como dispositivo clínico: intervenções com famílias}

Dissertação apresentada como requisito parcial para obtenção do grau de Mestre pelo Programa de Pós-Graduação em Psicologia (Psicologia Clínica) da PUC-Rio. Aprovada pela Comissão Examinadora abaixo.

Profa. Silvia Maria Abu-Jamra Zornig Orientadora Departamento de Psicologia - PUC-Rio

Profa. Rebeca Nonato Machado Departamento de Psicologia - PUC-Rio

Profa. Renata Machado de Mello Instituto de Psicologia - UFRJ

Rio de Janeiro, 29 de julho de 2020. 
Todos os direitos reservados. É proibida a reprodução, total ou parcial, do trabalho sem autorização do autor, do orientador e da universidade.

Nicole Xavier Meireles

Graduou-se em Psicologia na Universidade Federal do Rio de Janeiro em 2017 e concluiu o curso de Pós-Graduação a nível de especialização em Terapia Através do Movimento: corpo e subjetivivação na Faculdade de dança Angel Vianna em 2018. Participa como psicóloga clínica do Espaço Colaborativo Semear e integra a diretoria da ONG Casa da Árvore, onde atua também como psicóloga.

Ficha Catalográfica

Meireles, Nicole Xavier

O brincar como dispositivo clínico : intervenções com famílias / Nicole Xavier Meireles ; orientadora: Silvia Maria Abu-Jamra Zornig. 2020.

87 f. ; $30 \mathrm{~cm}$

Dissertação (mestrado)-Pontifícia Universidade Católica do Rio de Janeiro, Departamento de Psicologia, 2020.

Inclui bibliografia

1. Psicologia - Teses. 2. Psicanálise. 3. Infantil. 4. Brincar. 5. Constituição subjetiva. 6. Psicologia. I. Zornig, Silvia Maria AbuJamra. II. Pontifícia Universidade Católica do Rio de Janeiro. Departamento de Psicologia. III. Título. 
Para todas as famílias que compartilham suas vidas comigo, dentro e fora do consultório. 


\section{Agradecimentos}

À CAPES e à PUC-Rio, pelos auxílios concedidos, sem os quais este trabalho não poderia ter sido realizado.

À minha orientadora, Silvia Maria Abu-Jamra Zornig, por me apresentar um novo mundo dentro da psicologia, pelo incentivo e paciência.

As professoras que compõem minha banca examinadora, por aceitarem meu convite e me prestigiarem com sua leitura sensível.

À Luana Moura, amiga tão presente e parceira fundamental para a conclusão destes escritos, que me apoiou e incentivou em todos os momentos, além de ler e revisar todos os meus textos.

Ao meu grupo de pesquisa, pelas trocas e discussões sempre tão ricas, em especial as minhas parceiras de mestrado Paloma, Bruna, Gisele e Isabela, pelos cafés, desabafos e mensagens de apoio.

À ONG Casa da Árvore e toda nossa equipe, pelo acolhimento e aprendizado, mas principalmente, por ser território que me (trans)forma.

Ao Felipe, Pither, Jimmi, Lulu, Renatinha, Sula e Bia, a melhor rede de apoio que alguém poderia ter, que me ensinam, na prática, o que é cuidado compartilhado.

À Mariana Carvalho, Raíssa Fontes e Juliana Souza, minhas parceiras de vida e de trabalho, que acreditam em mim e me contam isso, quase todos os dias.

As minhas amigas de vida, que Seja como Flor, estão do meu lado para tudo que eu preciso, sempre.

As minhas amigas mães, Isabel Svoboda, Raíra Yuma, Paula Dias, Juliana Maia, Laís Antunes, Raquel Potí, e tantas outras, por seguirem comigo nessa luta que é criar uma criança, pelos erros e acertos compartilhados.

Ao Rômulo, por compartilhar comigo essa experiência única que é criar o nosso filho, por me dar apoio e colo tantas e tantas vezes ao longo dos últimos anos.

À todas as familias que tive o prazer de acompanhar na minha prática clínica, que me inspiram para seguir estudando e exercendo meu trabalho.

À minha mãe, meu pai e minha irmã, por garantirem minha existência desde o primeiro dia da minha vida, pelo apoio incondicional e todo amor.

Ao Tom e a Maria, as crianças mais incríveis que poderiam existir.

O presente trabalho foi realizado com o apoio da Coordenação de Aperfeiçoamento de Pessoal de Nível Superior - Brasil (CAPES) - Código de Financiamento 001. 


\section{Resumo}

Meireles, Nicole Xavier; Zornig, Silvia Abu-Jamra. O brincar como dispositivo clínico: intervenções com famílias. Rio de Janeiro, 2020, 87p. Dissertação de Mestrado - Departamento de Psicologia, Pontifícia Universidade Católica do Rio de Janeiro.

O brincar se apresenta como parte fundamental do processo psíquico de construção da subjetividade, e assim, as primeiras trocas do bebê com a mãe ou adulto cuidador/a funcionam como as bases relacionais fundadoras do nosso psiquismo. Desse modo, a presente pesquisa se propõe apresentar o brincar como estruturante para o processo de constituição subjetiva a partir da intersubjetividade, se debruçando nas primeiras relações do bebê, no processo de integração egóica, na dificuldade de brincar do adulto e no setting terapêutico como ambiente facilitador. Para atingir esse objetivo o texto desenvolve a noção de continuidade e descontinuidade no processo de subjetivação, utilizando ilustrações clínicas para discutir como o brincar se apresenta no espaço terapêutico. A importância da presença da família no tratamento psicoterapêutico é ressaltada assim como uma possibilidade de criação de um vínculo terapêutico que possibilite a co-construção de uma nova história.

\section{Palavras-chave}

Psicanálise; infantil; brincar; constituição subjetiva; psicologia. 


\section{Abstract}

Meireles, Nicole Xavier; Zornig, Silvia Abu-Jamra (advisor). Playing as a clinical device: interventions with families. Rio de Janeiro, 2020, 87p. Dissertação de Mestrado - Psychology Department, Pontifícia Universidade Católica do Rio de Janeiro.

Playing is presented as a fundamental part of the psychic process of building subjectivity, and thus, the baby's first exchanges with the mother or adult caregiver function as the relational founding foundations of our psyche. In this way, the present research proposes to present the playing as structuring for the subjective constitution process from the intersubjectivity, focusing on the baby's first relations, in the egoic integration process, in the difficulty of playing with the adult and in the therapeutic setting as an environment facilitator. To achieve this goal, the text develops the notion of continuity and discontinuity in the subjectivation process, using clinical illustrations to discuss how playing presents itself in the therapeutic space. The importance of the presence of the family in psychotherapeutic treatment is highlighted, as well as the possibility of building a therapeutic bond that allows the co-construction of a new history.

\section{Keywords}

Psychoanalysis; infantile; playing; subjective constitution; psychology. 


\section{Sumário}

$\begin{array}{ll}\text { 1. Introdução } & 10\end{array}$

2. O brincar e a constituição psíquica 14

2.1. O primeiro tempo do brincar - a relação inicial mãe e bebê 14

2.2. O brincar: uma experiência criativa 22

2.3. A sensorialidade, o brincar e a constituição psíquica 26

2.3.1. O som da raiva 29

3. A Casa da Árvore - um espaço coletivo para brincar e conversar 36

3.1 A Casa da Árvore como ambiente facilitador 42

$3.2 \mathrm{O}$ encontro com o adulto cuidador 46

3.3 O brincar como processo 49

3.4 Tipos de brincar: o brincar auto-subjetivo, o brincar interativo e o brincar intra-subjetivo 53

4. O trabalho com a família 59

4.1 A dificuldade do adulto de brincar: uma atualização da infância vivida 61

4.2 A parte bebê do adulto 66

4.3 O brincar na família: co-construindo uma nova história 71

4.4 A família dentro do consultório psicoterapêutico 72

4.4.1 A ausência da família e a presença da criança - uma

$\begin{array}{ll}\text { experiência de descompasso familiar } & 74\end{array}$

$\begin{array}{ll}5 \text { Considerações finais } & 79\end{array}$

6 Referências Bibliográficas 83 
Outro dia eu estava saindo de casa para participar de um debate quando meu filho me parou na porta:

- Mamãe, o que você está indo fazer? - Estou indo conversar com algumas pessoas sobre o brincar, filho, você tem alguma sugestão do que não posso esquecer de falar? - Mas a gente não fala sobre o brincar, mamãe, a gente brinca.

(Tom, 3 anos) 


\section{1 \\ Introdução}

Diversas linhas da psicanálise enfatizam a importância das vivências infantis e das experiências familiares na formação psíquica do indivíduo. A observação do modo como bebês e crianças interagem com o ambiente, suas relações familiares e as formas de interação com outros infantes se apresentam como aspectos que definem um importante foco de interesse e pesquisa psicanalítica.

Espaços de convívio entre bebês, crianças e seus cuidadores podem ser vistos, desse modo, como importantes fontes de observação dessas interações. Nesse contexto, a presente dissertação se desenvolve a partir de questionamentos que surgiram na observação clínica do modo como as crianças e seus cuidadores se relacionam nos espaços de convívio da ONG Casa da Árvore.

A ONG Casa da Árvore foi fundada em 2001, como um espaço de convivência para crianças e famílias nas favelas do Rio de Janeiro, com o intuito de promover a ampliação do campo de intervenção psicanalítica. Inspirada, inicialmente, pela Maison Verte francesa de Françoise Dolto, a ONG foi criada como um projeto de extensão universitária da UERJ pelas psicanalistas Lulli Milman e Maria Fernanda Baines.

Trata-se de um espaço destinado a crianças, entre 0 e 10 anos, e seus cuidadores para que convivam com outras crianças e famílias na presença de profissionais - em sua grande maioria psicólogas - com um olhar sensível e atento para o cuidado com as singularidades de cada um. A aposta clínica é a criação de um espaço suficientemente bom, que auxilie no desenvolvimento saudável das crianças e adultos ali presentes.

A Casa da Árvore consiste em um dispositivo clínico de portas abertas, no qual não é necessário realizar uma inscrição prévia, que propõe a criação de um ambiente existencial, subjetivo, em que os limites e plasticidade se dão através da escuta afetiva do sujeito, da mediação pela palavra, do acolhimento do corpo e das trocas intersubjetivas. Nesse espaço, para além do modelo proposto por Dolto de 
circulação da palavra, hoje circulam corpos, gestos, movimentos, palavras e o silêncio, através de cada brincadeira.

O objetivo principal do trabalho dessa organização é a criação de um espaço seguro e confiável, que possa ser utilizado pelas crianças como base para seu desenvolvimento saudável, sendo acompanhadas por suas famílias nesse processo. As interações entre psicólogas, crianças e adultos são baseadas nas trocas propostas pelas brincadeiras. Na Casa da Árvore, o brincar é o elo que sustenta o trabalho com as pessoas que ali estão e a prática clínica.

Partindo da perspectiva de que o brincar é o primeiro passo de inserção do bebê na relação intersubjetiva, a presente dissertação busca entender como essa inscrição psíquica ocorre em famílias nas quais os adultos não apresentam essa disponibilidade emocional para as trocas iniciais com o bebê. A partir da observação das famílias nos espaços de convivência da Casa da Árvore e de algumas ilustrações clínicas, podemos ao longo deste trabalho, apresentar alguns materiais que servem como pano de fundo para esta discussão.

Os bebês possuem a necessidade vital de que alguém facilite os estágios iniciais dos seus processos de amadurecimento. Em seus primeiros momentos de vida, são absolutamente dependentes e é necessário que exista alguém com eles durante todo o tempo para que sejam cuidados e se sintam seguros. O psicanalista Donald Winnicott (1975) propõe a noção de que ambiente facilitador é aquele que permite que os processos evolutivos e as interações naturais do bebê com o meio se deem de forma saudável. Ele utiliza o termo "mãe suficientemente boa" para se referir à mãe, ou outro adulto cuidador que exerça essa função primordial, que fornece um ambiente propício para o desenvolvimento de seu filho.

A reflexão sobre o brincar como processo básico de constituição do psiquismo evidencia a importância de trabalhar mais a fundo as relações iniciais do bebê. Carências e falhas nessa fase podem colocar em risco toda a construção de subjetividade do indivíduo, dificultando o desenvolvimento psíquico e emocional saudável do bebê.

No contexto de trabalho clínico com as famílias, pode-se observar a dificuldade de muitas crianças de brincar, mas principalmente, o bloqueio de muitas mães e pais de estarem junto com elas nesse processo. Desse modo, o olhar clínico sobre as crianças pequenas e suas relações familiares se torna muito necessário. Diante desse cenário, onde o brincar se apresenta por vezes de modo tão confuso e 
desconexo, buscamos entender como a dificuldade de brincar pode atrapalhar na integração psíquica da criança e principalmente como a prática clínica pode auxiliar à família a tornar o brincar possível.

As principais questões deste estudo apontam para as dificuldades das relações entre adultos primordiais e os bebês e como a clínica psicanalítica pode funcionar como um espaço potencial que permite a construção de novas possibilidades de ser de cada um. Para isso, recorremos a autores como René Roussillon e Bernard Golse para refletir sobre os encontros e essas relações primordiais.

Winnicott (1975) introduz a ideia do brincar enquanto experiência criativa, inserida em um espaço-tempo, de forma contínua. O que pode ocorrer com a criança que vive essa experiência de forma precária? Como se instaura o brincar em um contexto no qual ele não está sendo possível? Como podemos observar essas possíveis falhas refletidas no corpo da criança?

Ao longo do primeiro capítulo, realizamos um estudo aprofundado das primeiras trocas entre mãe e bebê. O capítulo é introduzido com as teorizações de Winnicott acerca dos primórdios dessa relação, apontando para o caráter estruturante da experiência de continuidade do ser. Em seguida, analisamos os trabalhos de autores como Albert Ciccone e Alberto Konichekis para ressaltar a importância da sensorialidade no processo de integração egóica do bebê.

No segundo capítulo, a partir de uma ilustração clínica ambientada na ONG Casa da Árvore, analisamos o brincar dentro da clínica a partir de diferentes situações e intervenções. Nos debruçamos sobre o brincar na constituição psíquica, sobre as possíveis falhas nesse processo em determinadas famílias e sobre como o setting clínico pode atuar como ponte na busca de um desenvolvimento emocional saudável.

No terceiro capítulo, apresentamos como foco a família na clínica, pensando sobre a importância da presença dos cuidadores no tratamento psicoterapêutico. Analisamos a questão das dificuldades do cuidar entre adultos e crianças, da história psíquica de cada um e sobre a possibilidade de co-construir uma nova história com essas famílias.

O principal objetivo desta dissertação é realizar um estudo teórico sobre a função estruturante do brincar na constituição psíquica e quais são as repercussões do não-brincar familiar no psiquismo da criança. E assim, refletir sobre como o 
analista pode atuar como ambiente facilitador auxiliando as famílias a fazer emergir essa área do brincar e atingir seu potencial criativo dentro deste contexto.

Nesse sentido, uma reflexão sobre a importância do brincar enquanto dispositivo clínico se faz necessária como uma tentativa de auxiliar a reorganização psíquica das famílias. Tratar das crianças em um momento onde ainda estão em formação, pode ser crucial para o desenvolvimento saudável de cada uma, além de poder se colocar em uma função reparadora para os sintomas dos adultos.

Nossa hipótese com esse trabalho é refletir sobre o brincar não como uma brincadeira ou brinquedo, mas como um modo de percurso subjetivo. Com isso, ele está presente na clínica com crianças e famílias, em todas as trocas, experiências verbais e/ou sensoriais. É necessário que os agentes de cuidados estejam disponíveis para brincar junto com analista e criança, para podermos co-construir um espaço seguro, contínuo e confiável dentro do ambiente clínico, de modo que essa experiência possa reverberar para o espaço de fora. 


\section{2 \\ O brincar e a constituição psíquica}

O que propomos fazer neste capítulo é pensar sobre os primórdios da constituição psíquica e de como o brincar estrutura as primeiras trocas entre mãe e bebê. Lançar um olhar para a importância do brincar nos primórdios da organização psíquica é aprofundar um estudo sobre as relações, inseridas em diversos tempos e espaços.

A mulher que se torna mãe carrega em si muitas marcas de como foi cuidada quando era um bebê. Já possui em si marcas no corpo de toda uma vida de trocas e experiências com o outro. Desse modo, nos perguntamos: como isso ressurge e se recoloca na situação da maternagem? Até que ponto as dificuldades de brincar da criança não estão atreladas à uma dificuldade de brincar do adulto? Como podemos pensar uma relação entre eles?

\section{1 \\ O primeiro tempo do brincar - a relação inicial mãe e bebê}

A descoberta da gravidez é um momento único na vida de uma mulher e suas reações podem ser as mais variadas possíveis. Os meses que se sucedem serão marcados por um período extremamente sensível no qual é vivida uma relação muito forte da mulher com seu corpo. São muitos sentimentos, hormônios e informações que chegam a todo momento, criando uma nova rotina de vida. Sono excessivo, enjoos contínuos, dores nas costas, alteração rápida de humor, fome, são sintomas típicos que circundam a mulher nesse período. Durante nove meses é gerada uma vida dentro de si e essa é a primeira etapa de uma relação eterna entre mãe e bebê.

Maria Tereza Maldonado (1985) caracteriza a gravidez como um momento de crise, um período de perturbação temporária de um estado de equilíbrio, apesar de estar situada em um desenvolvimento saudável. Segundo a autora, nesse momento a mãe tem a necessidade de reestruturação e reajustamento em várias dimensões, pois está passando por um período de transitoriedade que ultrapassa as capacidades do sistema de adaptar-se interna e externamente, no qual ocorre uma 
mudança de identidade onde a mulher sai do papel de filha para ocupar, também, o papel de mãe, passando pela possibilidade de atingir novos níveis de integração, amadurecimento e expansão da personalidade.

Há sempre uma oscilação entre desejar ou não aquele filho. Não existe uma gravidez totalmente aceita nem uma gravidez totalmente rejeitada. Segundo a autora, a ambivalência afetiva é um fenômeno natural e caracteriza todos os relacionamentos interpessoais significativos. As grandes mudanças sempre virão com perdas e ganhos. A descoberta da gravidez pode não chegar como uma boa notícia para muitas mulheres, que por seus mais variados motivos, rejeitam o bebê no primeiro momento. Porém, a reação inicial não se cristaliza para sempre: é comum a rejeição dar lugar à aceitação e vice-versa.

A complexidade das mudanças trazidas pelo bebê não se restringe apenas as questões psicológicas e bioquímicas: os fatores socioeconômicos também são fundamentais. Na sociedade atual, encontramos uma mulher que é trabalhadora, responsável pelo orçamento familiar (por vezes exclusivamente), e cultiva interesses diversos, para além do cotidiano do lar. Logo, ter um filho acarreta consequências bastante significativas. Privações reais, sejam afetivas ou econômicas, aumentam a tensão e intensificam a sensação de ambivalência afetiva. Essas preocupações com as incertezas relacionadas ao futuro aumentam a frustração e, com isso, a raiva e o ressentimento que podem impedir de encontrar gratificação na gravidez. (Maldonado, 1985, p.22)

O significado simbólico de ficar modificada como pessoa após a experiência da maternidade traz o medo de não retomar a identidade antiga e transformar-se em outra pessoa - com mais perdas do que ganhos. A mulher sente seu organismo mais lento e tende a ficar mais retraída, concentrada em si mesma. Essa é uma etapa essencial para prepará-la para o período pós-parto. Todo o afeto e carinho que as mulheres demandam nesse momento são como um estoque que fazem para posteriormente repassar ao bebê.

Donald W. Winnicott (1987), pediatra e psicanalista inglês, explica que o período da gravidez será o pano de fundo e a base para o nascimento de uma nova relação mãe-bebê. O período dos nove meses é um tempo fundamental para a passagem de um tipo egoístico para outro, isto é, da mulher tirar o foco de si mesma para colocá-lo sobre o bebê, que está crescendo em seu ventre. Tal fator influencia não só a mulher, é um estágio de preparação para toda família. 
Winnicott (1987) propõe ainda que a regressão é um fenômeno esperado e bem-vindo durante a gestação. É um retorno da mulher ao seu próprio período de dependência, colocando-a em uma sensação de vulnerabilidade extrema. Em geral, essa mulher aceita ser tratada por médicas, enfermeiras, ou parteiras, eleitas por ela, que a acompanharão na ocasião do parto. É importante que essas pessoas, aliadas da família, possam acolhê-la nesse período temporário, propiciando à mãe um ambiente favorável, garantindo um bom desenvolvimento da gestação.

O conceito de regressão na clínica, dentro da teoria winnicottiana, se caracteriza por um mecanismo de retorno a uma situação de falha ambiental que ficou "congelada" pela crença na possibilidade de correção dessa falha, podendo ser responsável pela formação de um falso self. Segundo o autor, a regressão é parte de um processo de cura, que possibilita o paciente a se confrontar com os erros e falhas do ambiente. Ele faz uma analogia entre a maternidade quando a mãe funciona como continente para o bebê, atendendo suas necessidades principalmente no início da vida, e o papel do analista na clínica, que funciona como continente do paciente, acolhendo-o nas suas demandas.

Para a mãe, a realidade do feto no útero é totalmente diferente da realidade de um recém-nascido, por isso para muitas mulheres é muito difícil fazer essa transição. Enquanto durante a gravidez existe um cuidado muito grande com a mulher, um olhar atento sobre ela e suas necessidades - e consequentemente para o bebê que ela carrega - depois do parto, os olhares se voltam para o bebê. É preciso cumprir uma série de responsabilidades novas e situações nunca antes experimentadas, como amamentar, trocar fraldas, dar banho, acolher crises de choro, colocar o bebê para dormir.

Junto à satisfação da maternidade vem a responsabilidade de assumir novas tarefas cotidianas e de conviver com diversas limitações relacionadas à vida antes do bebê. É comum ficar confusa e assustada com a realidade de ter um recémnascido em casa, especialmente ao deparar-se com situações distintas da realidade que se imaginara durante a gestação. O puerpério se caracteriza por esse momento inicial dos primeiros dias da vida de uma mulher no pós-parto, de "retorno" do corpo e hormônios à flor da pele.

Winnicott (1999) no livro “Os bebês e suas mães”, defende que a mãe siga sua tendência natural de cuidados com o bebê. Usa o termo "mãe dedicada comum" para se referir à mãe que fornece um ambiente propício para o desenvolvimento de 
seu filho. Os bebês possuem a necessidade vital de que alguém facilite os estágios iniciais dos seus processos de amadurecimento. Já que nesse momento são absolutamente dependentes, é necessário que exista alguém com eles para que sejam cuidados e se sintam seguros. $\mathrm{O}$ ambiente facilitador é aquele em que os processos evolutivos e as interações naturais do bebê com o meio podem desenvolver-se de acordo com as necessidades do indivíduo.

Inicialmente, do ponto de vista do bebê, nada existe além dele próprio e a mãe é parte dele. Logo, o apoio do ego materno facilita a organização do ego do próprio bebê. Com o tempo ele vai se tornando capaz de integrar-se, se tornando uma unidade, capaz de afirmar assim sua própria individualidade e até mesmo de experimentar um sentimento de identidade pessoal.

No início da vida, o bebê ainda não estabeleceu uma divisão entre o eu e o não-eu. Com isso, o comportamento do ambiente faz parte dele, da mesma forma que o comportamento de seus impulsos hereditários, para a conquista de uma unidade psicossomática satisfatória. O período de dependência absoluta inicial, segundo Winnicott, se baseia no estado de preocupação e total atenção da mãe em relação ao bebê no qual o adulto primordial deve estar presente a todo momento.

Nessa fase, os bebês são afetados por tudo o que os rodeiam. São seres ainda extremamente dependentes e o tempo todo vivem experiências que são armazenadas em seus sistemas de memória. Essas vivências podem torná-los confiantes no mundo ou o contrário, deixá-los sem confiança nenhuma. No extremo da falha ambiental, que supõe essa falta de confiança, está um fator fundamental: a sensação de imprevisibilidade (WINNICOTT, 1987).

Winnicott (1956) aponta que existe um período denominado de “preocupação materna primária", no qual as mães se tornam capazes de se colocar no lugar dos seus bebês. Isto é, elas desenvolvem uma capacidade de identificação com o bebê que lhes possibilita satisfazer as necessidades básicas do recémnascido, de uma forma que nenhuma outra pessoa pode supor, nem ensinar. $\mathrm{O}$ ato de segurá-los explicita isso. Trata-se de um momento específico do encontro mãebebê, no qual o "segurar" permite ao bebê a criação de um senso de contorno corporal e de continuidade de existência.

A constância desse encontro constrói uma sensação de previsibilidade que é justamente a adaptação da mãe às necessidades do bebê, nesse estágio da preocupação materna primária. Dessa forma, a adaptação só pode ser 
suficientemente bem-feita se a mãe se dedica por completo aos cuidados com seu bebê.

Logo após a concepção, ou quando já se sabe que a concepção é possível, a mulher começa a mudar sua orientação e a se preocupar com as mudanças que estão ocorrendo dentro dela. De várias formas ela é encorajada pelo seu próprio corpo a ficar interessada em si própria. A mãe transfere algo de seu interesse em si própria para o bebê que está crescendo dentro dela (WINNICOTT, 1983, p.52).

Winnicott (1956) pontua que a preocupação materna primária é um estado organizado da mulher, ao final da gestação, no qual algum aspecto da personalidade assume o controle, temporariamente. Esse modo de extrema atenção e cuidado às necessidades do bebê é o que permite a continuidade de seu desenvolvimento, de seus processos de maturação.

Esse estado poderia ser comparado a um estado de retraimento, um estado dissociado, fuga ou algo a nível mais profundo como um episódio esquizoide que, se não fosse pela gravidez, seria considerado doença. A mãe que desenvolve esse quadro fornece um ambiente no qual as tendências do bebê podem se mostrar e o bebê pode experimentar um movimento espontâneo e dominar as sensações apropriadas nessa fase da vida (Winnicott, 1956).

Essa situação é possível porque a mãe, identificada com o bebê, regride ao seu estágio de bebê, ocupando seu lugar. O autor pressupõe que fracassos maternos nessa fase interrompem a "continuidade do bebê" fazendo-o reagir às invasões de modo excessivo, produzindo uma "ameaça de aniquilamento", uma ameaça à existência pessoal do self. Propõe que o bebê se comunicaria da seguinte forma:

Encontro você;

Você sobrevive ao que eu lhe faço a medida que

A reconheço como um não-EU;

Uso você;

Esqueço-me de você;

Você, no entanto, se lembra de mim;

Estou sempre me esquecendo de você;

Perco você;

Estou triste. (WINNICOTT,1987, p. 92)

A comunicação entre a mãe e o bebê contém uma dicotomia fundamental: a mãe já foi um bebê e por isso pode retroceder a formas de experiência infantil 
enquanto o bebê não pode apresentar a sofisticação de um adulto, pois ainda não o foi. Desse modo, a mãe pode ou não falar com o bebê, a língua não tem importância. Para o autor a forma que a mãe tem de se comunicar com o bebê é através do holding. A mãe não precisa saber o que está passando com ele, o desenvolvimento do bebê só pode ocorrer num contexto de confiança que decorre do fato de ele ser segurado e manipulado.

A busca pela integração é uma tendência inata do sujeito e a conquista dessa unidade egóica é fundamental para seu desenvolvimento saudável. Inicialmente não integrado, o bebê depende do ambiente para que gradativamente possa reconhecer essa unidade e garantir sua continuidade no espaço e tempo. Winnicott afirma que aquilo que chamam de bebê não existe, propondo que o bebê é composto pelo ambiente que o circunda - e a mãe é colocada por ele como sendo esse primeiro ambiente.

A capacidade da mãe de se adaptar às constantes mudanças do bebê permite que sua trajetória de vida seja relativamente contínua. O bebê assim passa, com facilidade, da integração ao conforto descontraído da não-integração, e vice-versa. O acúmulo dessas experiências torna-se, assim, um padrão e forma uma base de expectativas para ele. Ele passa a confiar nos seus processos internos que levam a integração de uma unidade. A separação entre o que é interno e o que é externo é baseada na experiência de confiabilidade - que só é conquistada a partir da ideia da previsibilidade.

Durante o tempo em que a mãe cuida do bebê ela está, continuamente, corrigindo suas falhas. Winnicott utiliza o termo "carência" para dizer sobre as falhas que não são corrigidas no devido tempo. A criança carente é aquela que após tomar conhecimento de falhas que foram corrigidas, vem experimentar uma falha não corrigida e sua tarefa passa a ser provocar condições nas quais possa se estabelecer um padrão de correção de falhas repetidas. Dessa forma, se constitui uma "comunicação do amor" pautada na relação entre um adulto que se preocupa em reparar essas falhas, mais do que evitá-las.

Existe uma grande diferença entre as falhas relativas da vida cotidiana e as falhas básicas que produzem no bebê uma inacreditável ansiedade. Winnicott as classifica entre: (a) ser feito em pedaços; (b) cair pra sempre; (c) completo isolamento, devido a inexistência de qualquer forma de comunicação; (d) disjunção entre psique e soma. Estes são os frutos da privação, das falhas no ambiente que 
não foram corrigidas. Diante desses possíveis cenários, o desenvolvimento do bebê poderá ser deturpado e a comunicação entrará em colapso (WINNICOTT, 1985, p.88).

As formas de comunicação mãe-bebê nestes momentos são, portanto, silenciosas. O que mantém a vivacidade é o contato, o cheiro da mãe, o barulho da sua respiração. $O$ embalar é uma garantia contra a despersonalização, ou rompimento da combinação psicossomática onde a reciprocidade é fundamental.

São nesses primeiros estágios de comunicação do bebê com a mãe que está se assentando as bases da futura saúde mental dele e podemos observar, no tratamento dos transtornos psíquicos, defrontamo-nos com as falhas iniciais dessa facilitação.

No artigo intitulado "Entre a palavra e o movimento" Hélia Borges (2011) aponta:

A constituição de um eu, para este autor (Winnicott), é vista neste texto como resultante de um processo em que não existe um eu desde o começo, mas sim uma soma de começos, ou seja, uma soma de experiências, de qualidades corpóreas, uma soma de sensorialidades e movimentos inaugurais, sendo este - a multiplicidade de inícios - o momento de integração, o momento onde o eu começa. (BORGES, 2011, p.93)

A autora propõe que, ao invés de pensarmos na constituição do ego como um caminho para estabilização de forças em uma única direção, pensemos nesse processo como algo que resulte em um ego que possibilite a sustentação da multiplicidade de vivências. $\mathrm{O}$ eu aqui se coloca como um campo de forças que convoca a ideia de ritmo, de corpo vivo, móvel, que realiza o sentimento de existir.

A recém-mãe utiliza seu corpo como expressão de um acolhimento que possibilita a integração. Esse acolhimento físico funciona como uma resistência aos movimentos realizados pela motricidade, permitindo que se crie um campo de contorno e oposição, fundamentais para a construção da subjetividade.

Quando o bebê olha para sua mãe ele enxerga a si mesmo. Esse papel de espelho exercido por ela proporciona ao bebê uma sensação de existência - "Quando olho, sou visto; logo, existo. Posso agora me permitir olhar e ver" (Winnicott, 1975, p.157). O bebê interage com a mãe a partir de uma dimensão sensorial do espelhamento e, para que isso funcione como um impulso a sua própria integração, precisa ser olhado de volta, na tentativa de obter algo de si mesmo. O resultado 
disso é um bebê que é capaz de usar o objeto e sentir como se este fosse um objeto subjetivo, criado por ele. Gradativamente, o bebê passa a perceber que o que ele vê é diferente dele. A separação entre o eu e o não-eu se efetua de acordo com o ritmo proposto na relação entre o bebê e o ambiente.

Albert Ciccone (2018), psicanalista francês, pressupõe que essa sensação de ritmicidade entre mãe-bebê, garante a continuidade de existência criando uma segurança interna que permite uma abertura da criança para o mundo.

É a partir das primeiras experiências de troca que essa construção se dá. O autor classifica três experiências rítmicas que pressupõe um desenvolvimento harmonioso e seguro do bebê: a abertura para o mundo e de retraimento sobre si mesmo; as trocas interativas e intersubjetivas; e as experiências de presença e ausência do objeto (2018, p. 15).

A abertura para o mundo permite que o bebê vivencie uma experiência nova da troca, e quando se retira para si mesmo, se permite interiorizar essa experiência para si, recriando-a internamente, fabricando sua subjetividade. Para isso, nas interações, é importante que o adulto cuidador respeite esse retraimento, no tempo/ritmo proposto pelo bebê. Como se o bebê conduzisse uma dança, onde o adulto possa garantir uma certa continuidade.

Esse fundo de continuidade permite que se dê uma quebra, gradual, de descontinuidade também. É na descontinuidade - segura - que se dá a criação. Sem o elemento surpresa, não há ritmo possível, A introdução de uma novidade permite que o bebê preencha com o seu próprio pensar o vazio momentâneo que o surpreende - permitindo aí uma diferenciação eu-outro. E essa troca se dá através do brincar.

As experiências de presenças/ausências do objeto também devem ser rítmicas. Na ausência do objeto, o bebê brincando recria em seu corpo a presença dele, com gestos e sensações. Porém esse tempo deve ser o possível para o bebê se sentir capaz de fazer essa recriação, se for excessivo pode deixá-lo no vazio.

Ciccone relaciona o registro do pulsional com o sensorial, o sensível, o perceptivo. São as pulsões que investem as sensações, as percepções sensoriais ou emocionais, e dessa forma desenvolvem-se as competências psíquicas do bebê. Assim, a dimensão rítmica seria justamente o elemento que proporcionaria uma liga de base para as diferentes experiências sensoriais perceptivas. Por outro lado, o ritmo não pode ser cogitado sem a intervenção e a presença do outro (Orth, 2018, p.34). 
Com isso, é a partir da intersubjetividade que surge pelo brincar que o bebê se constitui psiquicamente. O trabalho psíquico do objeto, segundo Ciccone (2011) se dá a partir de um compartilhamento de afetos. Ou seja, é preciso que haja uma experiência compartilhada de prazer entre adulto e criança para que se dê uma apropriação da experiência subjetiva pelo bebê, a partir do momento que o objeto respeita a ritmicidade dessa troca.

O fracasso no encontro com a continuidade nas experiências corporais desorganiza o bebê de modo que ele se torna incapaz de se apropriar da experiência. É necessário que haja uma certa previsibilidade que garanta sua continuidade de existência. Uma descontinuidade excessiva contribui para uma desorganização sensório-corporal, uma quebra, que interrompe o sentimento de continuidade de existência.

\section{2 \\ O brincar: uma experiência criativa}

Brincar não é só o ato de fazer comidinha de mentirinha, inventar um grande castelo ou jogar bola, o brincar começa a partir das primeiras trocas entre mãe-bebê. O brincar é toda a base do processo de constituição psíquica, de reconhecimento de quem sou eu e quem é o outro, e é a partir da relação intersubjetiva com nosso cuidador primordial - geralmente a mãe - é que se estabelece um eu integrado.

Esse início de troca é muito importante para o bebê e, como já citado anteriormente, para que isso se dê de forma saudável, é preciso que haja um ambiente facilitador que lhe proporcione essa experiência de continuidade. Ser cuidado por alguém que está atento as suas demandas e necessidades. Alguém que o alimenta quando está com fome, alguém que troca sua fralda, dá banho, carinho e colo. Tudo isso são os cuidados básicos necessários com um bebê, para que ele possa se desenvolver plenamente. E todos esses elementos são a base do brincar.

Quando um bebê coloca o dedo na própria boca, por mais que ele ainda não tenha consciência clara de que isso é uma forma de brincar, ele está brincando. É dessa forma que ele está descobrindo seu corpo, através de todos os próprios sentidos e sensações corporais. Quando o bebê coloca o dedo na boca do adulto cuidador, e espera uma relação dele, já é uma nova etapa do brincar, onde ele começa a enxergar que existe um outro ali; que o outro é outro e não ele mesmo. 
Winnicott defende a ideia de que o brincar tem um lugar e um tempo. Este lugar, segundo o autor, não é dentro - mundo interno -, tampouco é fora - mundo externo. Esse espaço se nomeia como espaço potencial e está localizado entre a mãe e o bebê. Os primeiros momentos da teoria da brincadeira estaria composta por: (A) bebê e objeto estão fundidos um no outro - a visão do bebê do objeto é subjetiva e a mãe se orienta no sentido de tornar concreto aquilo que o bebê está pronto para encontrar; (B) o objeto é repudiado, aceito de novo e objetivamente percebido - a mãe propicia ao bebê uma experiência de "onipotência", quando o bebê acredita que produz tudo aquilo que precisa - e é nesse ponto que o autor acredita que a brincadeira se inicia, neste playground imaginário (1975, p.70) - o espaço potencial.

A experiência de ilusão winnicottiana aponta para uma aposta na sensibilidade da mãe que, em estado de preocupação materna primária, proporciona ao filho o objeto no exato instante que ele o alucina - garantindo essa noção de previsibilidade. Desse modo, a mãe impede que o bebê viva a percepção da diferença eu-outro prematuramente. De modo gradativo e compartilhado, bebê e mãe vão criando possibilidades de transformar a ausência do objeto em algo possível e suportável, vivenciando o sentimento de continuidade de existência. Caso contrário, o bebê vive uma experiência de desamparo desestruturante.

É nesse momento em que o bebê estaria apto a iniciar seu processo de diferenciação com sua mãe. Através desse "playground imaginário" o bebê tem uma ilusão de onipotência, de controle mágico do objeto. “A mãe (ou parte dela) se acha num permanente oscilar entre ser o que o bebê tem capacidade de encontrar e (alternativamente) ser ela própria, aguardando ser encontrada" (Winnicott, 1975, p.70). A importância do brincar é sempre a precariedade do interjogo entre a realidade psíquica pessoal (subjetivo - quase alucinação) e a experiência de controle de objetos reais (o que é objetivamente percebido - realidade concreta ou realidade compartilhada).

O momento seguinte $(\mathrm{C})$ é ficar sozinho na presença de alguém a partir da suposição de que a pessoa a quem se ama (que é digna de confiança e por isso lhe dá segurança) está disponível e permanece disponível quando é lembrada após ter sido esquecida. Em seguida, (D) a criança está se preparando para permitir e fruir uma superposição de duas áreas da brincadeira (Winnicott, 1975). 
É a partir dessa primeira experiência de onipotência que se origina a brincadeira. A capacidade da mãe de fornecer ao bebê o seio no exato momento que este o deseja gera nele a crença de que o seio seria assim fruto da própria criação. Desse modo, o bebê possui uma ilusão de que existe uma realidade externa correspondente à sua própria capacidade de criar. A tarefa da mãe, assim, é ir gradativamente o desiludindo.

A característica essencial do que desejo comunicar refere-se ao brincar como uma experiência, sempre uma experiência criativa, uma experiência na continuidade espaço-tempo, uma forma básica de viver. A precariedade da brincadeira está no fato de que ela se acha sempre na linha teórica existente entre o subjetivo e o que é objetivamente percebido. (WINNICOTT, 1970, p.75)

Essa área intermediária é essencial para o início de um relacionamento entre a criança e o mundo e ela só pode ser criada se é estabelecida uma relação de continuidade entre ambiente-bebê. Esse sentimento de continuidade surge a partir da previsibilidade - da capacidade materna de responder as demandas do bebê.

O sentimento de confiança por parte do bebê na mãe é fundamental para que se crie o espaço potencial. Essa confiança está intimamente relacionada com a fidedignidade da figura materna ou dos elementos ambientais - isto é, no sentimento de previsibilidade.

Em primeiro lugar, é a mãe quem brinca com o bebê, na preocupação de ajustar-se às suas necessidades e atividades lúdicas. À medida que lhe é possível, vai introduzindo o seu próprio brincar, visualizando assim como é a capacidade de resposta do seu bebê, de aceitar ou não o que lhe é proposto. Assim, se abre o caminho para um brincar conjunto em um relacionamento.

O brincar é o espaço onde o encontro se dá. É através do brincar, da intersubjetividade, que o bebê constrói à subjetividade. Bernard Golse (2003) coloca o brincar como um espaço de narração mútuo, tanto com crianças quanto com bebês. Os encontros entre a dupla adulto-bebê trazem um encontro singular no qual o adulto traz toda sua história na sua interação e capacidade de sintonização e harmonização de afetos, mas também precisa lidar com o impacto desse bebê no seu mundo representacional. $\mathrm{O}$ adulto não deve demandar que o bebê seja reflexo da imagem dele nem tampouco o bebê deve demandar que os adultos funcionem 
como suas primeiras imagos. Nesses encontros, um tenta modificar o outro, aceitando modificar também a si mesmo.

O brincar permite a descoberta do outro, um outro que possa atuar como um espelho, parecido com ele, mas também não-parecido. Esse espaço de brincar precisa da liberdade que vai se criar, ou não, para que se deem os encontros e para que haja efeitos deles (Golse, 2003).

Só é possível brincar junto se existe uma experiência de prazer compartilhado. A narratividade do adulto só faz sentido para a criança se ele experimenta prazer nessa atividade, criando um fundo, um clima emocional, de disponibilidade para o compartilhamento de afetos de prazer.

Todo brincar, relacional ou não, tem um valor de atividade de ligação; vemos bem como a narratividade do outro e o prazer que ele retira daí intervêm como condição sine qua non do futuro brincar da criança, trate-se de um brincar relacional ou não. (Golse, 2003, p. 48).

$\mathrm{O}$ autor aponta que enquanto a criança convoca o outro a brincar, os bebês exigem que brinquemos com eles. Essa ideia de ter o calor de uma atividade de ligação se relaciona intimamente com a ideia de um ego inicialmente fragmentado. É a partir do outro que o auxilia nessa integração que o bebê se permite ser - e isso só pode se dar a partir desse compartilhamento de afetos.

No início da vida, no que Winnicott (1963) chama de dependência absoluta, apesar de ainda extremamente dependente do apoio e cuidados maternos, o bebê já se permite explorar seus próprios recursos para ascender à formação egóica. É importante que nessa fase ele seja estimulado a essa exploração, permitindo que ele possa se descobrir pouco a pouco.

A mãe funciona como um fundo de contato contínuo que permite garantir a ritmicidade esperada para o desenvolvimento do bebê. A mãe que olha nos olhos de seu filho e lhe oferece carícias e cosquinhas, está situando essa criança em um lugar de troca, onde o bebê começa a estimular seu psiquismo ao conectar todas essas mini-percepções.

Ciccone (2011) classifica como uma manifestação do caos interno, na desordem disrítmica, a inconsolabilidade do bebê. Dessa forma, o grito, o choro inconsolável e a agitação são formas de projetar para fora algo que é do interno que não se sustenta. Porém, segundo o autor, mesmo nesses casos, existe uma tentativa do bebê de voltar para uma sensação base de ritmicidade. 
Winnicott (1974) pontua essa desordem, como uma experiência de aniquilamento do self, um medo de se fragmentar. Essa situação pode se colocar como um trauma a partir da sensação de angústia causada pela experiência de vazio absoluto, quando o bebê não tem ninguém a quem recorrer para lhe consolar. Isso pode se perpetuar na psique do adulto, como uma agonia primitiva, um medo do colapso, como nomeado pelo autor.

De certa forma, todos os bebês passam por essa experiência de falta de amparo sob alguma circunstância, porém o trauma pode surgir quando o grau de inconsolabilidade é mais intenso. Desse modo, esse vazio gera uma experiência de desamparo demonstrando como a ausência prolongada dos objetos primordiais antes da possibilidade de uma representação de sua ausência pode ser excessiva para o infante e gerar angústias primitivas.

A criança que, por algum motivo, não contou com a presença de uma mãe disponível, nem com outro adulto cuidador que exercesse essa função, terá grandes dificuldades de constituir um fundo contínuo de base psíquica para se ancorar. A mãe disponível é uma pessoa que se adapta ativamente as necessidades do bebê tanto as psicofísicas quanto as relacionais, onde o brincar se estabelece. Não ter essa figura brincante, que permite realizar um encontro de prazer compartilhado, pode ser impeditivo para que essa criança possa construir um sentimento de existência e continuidade do ser.

Entendendo a constituição psíquica como sendo formada desde o início da vida, com a relação intersubjetiva como estruturante inicial, e a mãe - ou alguém que exerça essa função materna - como objeto primordial nessa relação, como se dá essa construção nos casos em que essa figura estabelece precariamente a ritmicidade presente no brincar?

\section{3}

\section{A sensorialidade, o brincar e a constituição psíquica}

Ritmo, troca, corpo... do que se constitui o brincar? Brincar com uma criança, tanto na família quanto na clínica, é emprestar seu próprio corpo para essa relação. É servir de objeto, se deixando usar e compor por essa troca. O corpo do adulto funciona como um para-raio de experiências - um auxílio para a criança. 
As primeiras interações mãe-bebê já estão aqui colocadas como formas de brincar, como um momento de compartilhamento afetivo entre um adulto cuidador e seu bebê. E qual seria a via primordial para essa troca que não a via sensorial? As múltiplas informações que chegam a cada segundo no bebê, vão - gradualmente construindo seu ego, resultado da grande soma desses pequenos começos, como pontuamos anteriormente na fala de Hélia Borges. Vale ressaltar que essa totalidade não é adquirida de forma rígida, mas de uma forma fluida, que se forma e deforma ao longo de sua vida.

Alberto Konicheckis (2018), coloca que o processo de subjetivação dá conta da instauração de uma subjetividade a partir desse ainda-não-sujeito, em suas palavras: "o processo de subjetivação busca estabelecer um sentimento fantasmático e sensorial de continuidade no existir nesse tempo onde, continuadamente, se produzem descontinuidades" (p. 75).

\section{A continuidade garante a confiança e a previsibilidade. A} descontinuidade permite que o bebê possa criar em meio a algo que falta. É preciso que exista essa alternância entre os dois para que o processo de subjetivação do bebê possa acontecer. As primeiras experiências de um bebê são todas fragmentadas, e nesse início, é providencial que exista alguém que lhe dê uma sustentação, um contorno para essas experiências.

Konichekis (2018) propõe a noção de identidade sensorial que seria uma busca em sentir em si mesmo algo que já foi compartilhado com o outro. Dessa forma, o autor acredita que tem um registro corpóreo que permanece em si e não necessariamente é representado - ele se define pela intensidade das suas sensorialidades que instauram esse espaço pessoal e fundador do sentimento de si.

O sensório delimita e fornece uma espécie de cartografia que permite estabelecer os limites, as fronteiras, diferenciações entre si e os outros a partir de uma experiência interna própria, pessoal, mesmo que ela seja tão múltipla quanto variada. Os contínuos movimentos de vai e vem entre os fenômenos sensoriais de superfície e a profundeza do intimo participam também do estabelecimento de um sentimento de identidade. (Konichekis, 2018, p.80)

Os ritmos supõem essa noção de continuidade, de repetição, de retorno. As canções de ninar, por exemplo, o balanço do corpo, a tonalidade da voz, geram no bebê uma sensação de confiança e conforto, que tende a levá-lo ao apaziguamento. 
O autor chama esse processo de transmodalidade sensorial, no qual é possível retomar outras sensações vividas outrora para a presentificação de um modal. Como o processo de distanciamento da criança no colo sendo ninada e aninhada, para o momento em que ela é colocada no berço e o adulto continua entoando a canção. A partir de uma sensação, outras são revividas no corpo - a partir da memória sensorial.

O corpo materno, o laço maternal, enquanto qualidade de afeto, é anterior à formação psíquica da representação da mãe. Ser sustentado pelo outro configura se afastar um pouco de si para se auxiliar no outro. Seu sentimento de continuidade de existência se ampara no corpo do outro, no prolongamento de seu espaço corporal. Sendo assim, o sentimento de existência do objeto aporta, em troca, o sentimento de existência da criança (Konichekis, 2018).

A continuidade de ser se coloca, ao longo de toda a vida, como uma questão fundamental: sua preservação equivale à saúde. Todas as suas necessidades circulam ao entorno de ser e ter que continuar a ser. No início da vida, é o ambiente que lhe garante esse sentimento.

Segundo Konichekis (2018), a representação assim se forma a partir desse compartilhamento de experiência sensorial entre criança e ambiente. Se o ambiente falha, o objeto pode ser sentido pela criança como um dilaceramento de sua própria existência. $\mathrm{O}$ infante, desse modo, pode se defender desse cenário assumindo o lugar do próprio objeto, como uma proteção contra o excesso de suas descontinuidades, diminuindo ao máximo suas diferenças com ele.

É desde a vida intra-uterina que o bebê começa a ter essas primeiras sensações e trocas com a mãe, possivelmente já criando um certo "estoque" de memórias corporais. Desde esse início, Winnicott aponta para uma questão fundamental: a oposição entre espontaneidade e reatividade.

Para descrever esse momento inicial, Winnicott recorre a uma analogia que lhe foi sugerida por uma paciente: o bebê, ou o feto, é como uma bolha. Se a pressão externa está adaptada à pressão interna, a bolha pode seguir "existindo". Tratando-se do bebê humano, dizemos que ele continua "sendo". Se, por outro lado, a pressão no exterior da bolha for maior ou menor do que aquela no seu interior, a bolha passará a reagir à intrusão: ela se modifica como reação a uma mudança no ambiente e não a partir de um impulso próprio. Para o ser humano, isto significa uma interrupção do ser, produzida pela reação à intrusão. Cessada a intrusão, a reação também 
desaparece, e pode haver, então, um restabelecimento da continuidade de ser (DIAS, P. 159).

Desse modo, ao invés de usufruir de sua potencialidade criativa, o bebê se vê obrigado a reagir ao ambiente para conseguir garantir sua existência. Ele passa a ter de se relacionar com um mundo assumindo uma postura de alerta, vigilância, oriundo da possibilidade de uma intrusão. A rigidez ou a inaptabilidade da mãe, oriundas de uma ansiedade ou de estados depressivos, geram uma certa instabilidade materna com variações de humor que podem ser sentidas pela criança - através dos batimentos cardíacos, por exemplo - desde a gravidez.

A intrusão ocorre quando a mãe responde de acordo com suas próprias necessidades e não em função das necessidades do bebê. Nesse descompasso, o bebê reage para sentir-se vivo - o que quebra sua continuidade de ser. Sendo assim, enquanto o bebê está reagindo, ele não está "sendo".

O gesto espontâneo surge a partir de estar vivo e sentir suas experiências reais. A integração de sua personalidade se dá a partir do acúmulo dessas experiências, sensoriais e relacionais. A reação subtrai algo de um viver verdadeiro, distanciando-o de um viver espontâneo e criativo, levando a criança à um enrijecimento. $\mathbf{O}$ brincar só é possível quando existe espontaneidade.

A partir disso, veremos a seguir um caso que aponta para essa relação entre mãe e bebê, onde a criança reage agressivamente a esse ambiente que o invade.

\subsection{1 \\ O som da raiva}

Nesse ponto, podemos pensar na clínica com crianças e famílias como um espaço entre os excessos: ou de presença ou de ausência. Um espaço que permita se reestabelecer um ritmo entre esse contato adulto cuidador e criança. Abrir um espaço, uma brecha, entre um e outro, para que cada um possa estar junto e também separado do outro.

Chega para o atendimento clínico um menino de 4 anos, Rodrigo, com o encaminhamento da escola para acompanhamento psicológico com queixa de agressividade, dificuldade de se relacionar com as outras crianças, hiperatividade e dificuldades com limites. Na sua entrada, é difícil enxergar, ao certo, quem chega ao atendimento mais raivoso: a mãe ou a criança. Com a cara amarrada e uma 
descrença total naquele atendimento, ambos chegam sem aparente vontade de estar ali.

Ao longo dos encontros, Rodrigo vai percebendo que talvez aquele seja um espaço interessante - cheio de brinquedos e pessoas disponíveis para lhe dar atenção. Percebe, aos poucos, que ali é um lugar em que pode brincar, correr, trocar - sem tantas regras impostas. Já a mãe, parece bastante receosa naquele trabalho: como brincar pode curar os problemas do seu filho? No contexto do discurso escolar, ir até a psicóloga pode soar como um castigo destinado àquelas crianças que não se comportam bem. Como pode a criança chegar nesse atendimento e se divertir?

A clínica psicanalítica, fundamentada pelo pensamento winnicottiano de que o brincar é por si só terapêutico, acredita que é por essa via que acessamos os medos, desejos e angústias das crianças. E assim, buscamos criar no setting um espaço seguro e confiável para que as crianças possam estar disponíveis para essas trocas. Não é pelo medo, castigo ou intimidação, mas por um compartilhamento de afetos.

O trabalho terapêutico assim, não se faz apenas com o infante, mas com sua família e adultos cuidadores também. Além de olhar Rodrigo, precisávamos também olhar Maria, sua mãe, que estava ali em uma tentativa desesperada de ajuda. Com sua voz, alta e forte, ela invadia todo o ambiente.

Na fala de Maria, Rodrigo aparece como uma criança que sobreviveu a todas suas tentativas de aborto. Ela não queria esse filho, disse repetidas vezes, com muita raiva na voz. Ela assume que deve cuidá-lo, já que nasceu, mas que ele é impossível. Parece apresentar um discurso no qual localiza, desde a gravidez, sua falta de desejo pelo menino.

Ela diz sobre uma dificuldade inicial no desenvolvimento dele, pontuando que foi sempre muito tardio. Demorou para falar, para andar, para todas as conquistas esperadas, atrasou. Nada em Rodrigo parece ser de seu agrado - o filho que ela descreve é uma criança impossível de ser amada.

No lado da criança, nos chega um menino bem sensível a irritação. Qualquer "não" é motivo para jogar tudo no chão, bater e se revoltar contra tudo e todos. Tem um rosto bem franzido, sempre em alerta. Quando tentamos lhe dirigir a palavra sempre revida com algum som de raiva. Parece se esforçar para demonstrar que é bem bruto e irritado. 
A raiva entoada pela mãe parece penetrar toda pelo pequeno corpo de Rodrigo. Ele, por sua vez, reage, a todo momento. Ao ouvir qualquer fala da mãe se queixando dele, levanta e joga tudo no chão. Quebra algum brinquedo. Destrói algum objeto. Na sensação de estar sempre sendo destruído pela mãe, destrói seu entorno.

No atendimento clínico, buscamos resistir à destruição dos dois. Tanto de Maria, que tenta a todo tempo invalidar nossa atuação ali, quanto a de Rodrigo, que desconta toda sua raiva em nós e nos nossos materiais. Um longo trabalho foi realizado até isso se transformar e eles poderem começar a estabelecer conosco algum tipo de laço afetivo positivo.

Com o tempo e a criação de um espaço terapêutico de confiança, Rodrigo se mostra ser um menino muito carinhoso e atento: se lembra das brincadeiras da sessão anterior, repete aquilo que gosta e rememora situações que ele pode aproveitar. Certo dia, chegou para o atendimento correndo para um abraço - um gesto bem afetuoso que diz de uma relação de troca sincera e carinho. Nesse momento, a mãe logo começa a dizer o tanto de besteira que ele fez ao longo da semana... como se não tivesse espaço para essa qualidade de afeto.

Essa vinheta clínica ilustra uma situação em que o ritmo possível que mantém a relação dos dois é pela via de um afeto agressivo de raiva. A grande dificuldade de a mãe poder trocar qualquer tipo de carinho com o corpo do filho resulta em um corpo extremamente duro e enrijecido. Nem ele, nem ela, conseguem chorar. A identificação entre ambos é tamanha que não há um espaço entre eles em que seja possível advir alguma fórmula diferente dessas que eles criaram para essa relação.

O afeto é trocado a partir da raiva, da briga, da irritação. Nada surge além disso. Na conversa com a mãe, depois de muito tempo de convívio, pudemos começar a ouvir um pouco mais sobre sua própria infância, sobre o modo como foi tratada, sobre como precisou se enrijecer para suportar todas as dores. Como seria possível ela fazer algo de diferente com o filho?

As primeiras experiências sensoriais do bebê não possuem significações imanentes. Elas são parcelárias, fragmentárias e descontínuas. O próprio da atividade psíquica consiste em ligá-las. Em sua origem, as satisfações tanto quanto as inadequações, por falta ou por excesso, por parte dos adultos que se ocupam do bebê são experimentadas pelo bebê como uma experiência sensorial. (Konichekis, 2018, p. 79) 
Maria, na sua relação com Rodrigo, revive e reatualiza quem foi criança, trazendo à tona na sua forma de maternar não só quem era mas quem ela se transformou com tudo que viveu ao longo de sua vida. Não se trata de um reviver a sua infância, mas de uma possibilidade de enxergar hoje quem ela é após ter passado por tudo isso. A Maria criança é quem ela é na relação mãe-filho. Todo seu corpo é reflexo disso. Assim como seu filho.

Para Winnicott a agressividade é inata do ser humano, é inerente do estar vivo. Porém, ela só se desenvolverá a partir de um certo grau de amadurecimento, de integração dessa manifestação psíquica. Nos casos em que isso não ocorre, sua expressão se coloca como uma reprodução de algo que se vê, e não algo que é criado por si mesmo.

Se o ambiente fornece cuidados satisfatórios e se mostra capaz de reconhecer, aceitar e integrar essa manifestação do humano, a fonte de agressividade - que, no início, é motilidade e parte do apetite - torna-se integrada à personalidade total do indivíduo e será elemento central em sua capacidade de relacionar-se com outros, de defender seu território, de brincar e de trabalhar. Se não for integrada, a agressividade terá que ser escondida (timidez, autocontrole) ou cindida, ou ainda poderá redundar em comportamento anti-social, violência ou compulsão à destruição (Dias, 2000).

É importante ressaltar que a agressividade e a destrutividade são aspectos constituintes da noção de realidade externa. É através da destruição do outro e da sobrevivência do objeto que se inaugura a externalidade e a possibilidade de uso do objeto. Sem essa conquista, esse processo de integração egóica é impossibilitado. O amor e o ódio só podem se constituir se existe essa base.

Desse modo, no caso de Rodrigo, esse processo não se estabeleceu de modo satisfatório, pois nesse ambiente a agressividade de Rodrigo não pode ser reconhecida e aceita. Maria não pode ser destruída para em seguida sobreviver. Sendo assim, a única expressão de agressividade possível é a que a mãe lhe dirige, e, através da identificação, ele a repete, reproduz, sem passar pelo processo de experiência psíquica própria - resultando em uma possível compulsão a destruição.

Tratar de Rodrigo é tratar de Maria. Acolher o corpo de Rodrigo, trazê-lo para um brincar possível, com um afeto diferente da raiva, é fazer isso com o corpo dela também. E é a partir do brincar que se cria essa brecha, essa possibilidade para a criatividade, para a criação de novos mundos possíveis. 
A função da atividade psíquica, como aponta Konichekis (2018), é justamente integrar as experiências sensoriais fragmentadas. E essa organização nem sempre se dá de um modo leve e fluido - o dito "saudável". Por vezes é necessário esse endurecimento para sobreviver. A questão de Rodrigo não está ligada a uma falta de integração inicial, mas de uma integração pautada em muita raiva, dor e sofrimento. Pouco fluida e extremamente rígida. Como podemos criar um espaço em que ele possa ser mais livre, trocar carinho e outros afetos de vitalidade?

Konichekis defende que a sensorialidade se apresenta como um lugar de impacto, do encontro entre sujeito e objeto, como uma cena sexuada - no sentido de uma pulsão que exige um trabalho da psique. É do diferencial entre bebê e a mãe, da estranheza que nasce algo de si. É dessa interpelação que ele encontra sua identidade - no encontro com o outro.

A subjetivação consiste em se apropriar dessas experiências depositadas na pessoa e despertadas pelas experiências subsequentes. Por um jogo sutil de desligamentos alianças e religações, a criança busca encontrar o antigo e o novo, a repetição e a diferença. Cada experiência sensorial, inclusive a mais precoce, prova então ser ao mesmo tempo presente e passado, única e recorrente, prazerosa e perturbadora. Com esses elementos heterogêneos, o psiquismo compõe sua melodia pessoal (Konichekis, 2018, p. 87).

Desse modo, ao mesmo tempo em que a criança se encontra criando novas experiências sensoriais, também está nessa posição o adulto. E é a partir desse novo encontro que este pode ressignificar fatores ocultos de sua própria vida. A criança, reproduzindo esses traços, recoloca-os em cena, permitindo assim revisitá-los. E é no setting analítico que isso pode se dar junto da presença de um profissional capaz de ampará-los revivendo essas experiências sobre um novo ponto de vista.

Ainda segundo Konichekis, tanto quanto as experiências traumáticas, as sensorialidades são chamadas para se repetir e se reproduzir. Ele chama de embriões de sentido essa experiência sensorial que carrega infinitas possibilidades - de crescimento e perturbações patológicas. É sobre eles que trabalhamos, àquilo que se repete, que se recoloca a cada nova cena.

Para sair de um círculo vicioso patológico de dor e destruição de todos os envolvidos, é necessário um olhar atento sobre essa sensorialidade. Sobre os primórdios da vida não só da criança trabalhada como de sua família. O cuidado, a 
escuta e a disponibilidade são vias de acesso possível para irromper a repetição incessante que não prevê uma reorganização.

O ego em última análise deriva das sensações corporais, principalmente das que se originam na superfície do corpo. Ele pode ser assim encarado como uma projeção mental da superfície do corpo, além de representar as superfícies do aparelho mental. (FREUD, [1927] 1996)

Quando Freud ressalta a importância das sensações corporais na formação do ego, ele abre a brecha para um olhar mais sensível da escuta clínica, não só pela via da palavra como pela via do corpo. O corpo que hospeda a história daquela pessoa, suas trocas pelo contato, toque e pele. Suas memórias olfativas e gustativas. Sonoras. Quem nunca entrou em um ambiente repleto de um cheiro que transporta imediatamente para algum outro tempo e espaço?

Não à toa o estudo da constituição psíquica aqui é feito a partir da ideia de sensorialidade. De um corpo relacional que afeta e é afetado pelo outro. Um corpo que funciona como um depósito de sensorialidades que compõem um psiquismo que possui como atividade principal organizá-las. Konichekis (2018) pontua que as palavras ouvidas pelo bebê não lhe transmitem seu sentido representacional propriamente dito de início, mas soam como grãos, sementes de sentidos, formando um tesouro auditivo interno - onde se desenvolvem ou não. Ao invés de ruídos sem sentido, as palavras ouvidas pelo infante contêm embriões de sentidos, ou seja, significações em potencial.

Com isso, é imprescindível ressaltar o caráter estruturante dessas trocas iniciais com o bebê para a formação de seu aparelho psíquico. Um corpo endurecido que precisa se defender esconde um aparelho psíquico rígido, com pouca possibilidade de criação. Um e outro estão interligados, nesse formato relacional.

E como esse corpo brinca?

O brincar pressupõe a capacidade de criação de novos mundos. No que tange a ideia inicial de Freud (1908), fala sobre a possibilidade de ser ativo em um processo de experienciar um prazer reajustando recursos da realidade para sua criação. Um corpo rígido vai encontrar muita dificuldade nesse processo de deformação da realidade. A concretude, de muitas formas, impede essa possibilidade de criação. 
Desenrijecer, deixar descarregar, desobstruir as vias de satisfação pulsional. Um corpo rígido retém, não permite fluir. É o nosso trabalho, enquanto psicoterapeutas, atuar nessa desobstrução, atentando nosso olhar para o resgate do prazer e da libido retidas - criando a possibilidade de brincar junto.

É necessário - em qualquer tipo de análise - para que algo possa ocorrer uma certa relação transferencial, de confiança, entre analisando e analista. Nessa situação, de atendimento a famílias, a relação se baseia não na troca entre dois mas sim, no mínimo entre três: criança, adulto cuidador e analista. A brincadeira surge a partir dessa conquista.

O brincar é uma troca entre sujeitos. Trazer essa possibilidade para o setting é co-construir com eles essas novas possibilidades de mundo. Olhar para o sentimento individual de cada um dos agentes da família, da troca de cuidados entre eles inaugurando novos caminhos possíveis. 


\section{3}

\section{A Casa da Árvore - um espaço coletivo para brincar e conversar}

Com o objetivo de nos debruçar um pouco mais sobre a noção da função estruturante do brincar para a constituição psíquica, trazemos aqui uma ilustração clínica de um atendimento realizado em um dispositivo coletivo proposto pela ONG Casa da Árvore (CDA). Para entender melhor sobre as questões acerca do caso e o espaço clínico criado pela CDA, se faz necessária uma breve explicação sobre o trabalho realizado dentro dos chamados "Espaços de Convivência" desta ONG.

A ONG Casa da Árvore é apresentada para seus frequentadores como um espaço terapêutico para brincar e conversar. A equipe se compõe por, aproximadamente, 20 profissionais, que se reúnem semanalmente para estudar e discutir sobre o trabalho. Atualmente, a Casa da Árvore atua em dois lugares: no Morro da Conceição, em Niterói/RJ e dentro de uma Clínica da Família no Rio de Janeiro/RJ. Guardadas suas especificidades, o modelo de trabalho - em ambos os espaços - apontam para um lugar sem horário definido, sem inscrição ou qualquer obrigatoriedade de frequência.

No espaço localizado em Niterói, a CDA funciona durante cinco dias na semana, e, a cada dia, as equipes - formadas por três profissionais e em sua grande maioria psicólogos - oferecem a todas as crianças e adultos que chegam, um espaço de acolhimento e troca de experiências.

A aposta clínica é a criação de um espaço suficientemente bom, que permita estimular o desenvolvimento saudável das crianças e adultos ali presentes. Ou seja, mais que um dispositivo clínico de porta aberta, o encontro na Casa da Árvore propõe a criação de um ambiente existencial, subjetivo, em que os limites e plasticidade se dão através da escuta afetiva do sujeito, na mediação pela palavra, acolhendo, legitimando e sustentando suas necessidades e experiências.

E como é esse espaço? Como ele pode se configurar a partir da noção de "suficientemente bom"? Acreditamos que, através da conquista de confiança das crianças e famílias, podemos, aos poucos, construir com eles essa noção de espaço 
seguro. Rodeado por brinquedos, sofá, mesinhas, cadeirinhas, livros, cabaninha, materiais de artes, água, café fresquinho e profissionais disponíveis para um trabalho coletivo, atentos para as demandas das crianças e seus cuidadores, nos esforçamos para co-construir um espaço de troca e acolhimento contínuo.

A escolha da localização desses espaços de convivência se dá por uma aposta em lugares de maior vulnerabilidade socioeconômica, levando em conta as especificidades das famílias e crianças atendidas no local. Situadas nos entornos de favelas do Rio de Janeiro, a CDA se coloca como um recurso frente a um relativo desamparo social, político e psicológico. A valorização da criança como sujeito surge aqui como um respiro em meio à uma caldeirão de tensões. $\mathrm{O}$ trabalho coletivo permite que todos possam usufruir de um espaço seguro permeado por trocas, palavras, gestos e afetos. Nas palavras de Benilton Bezerra, um dos idealizadores desse projeto:

As Casas (da Árvore) estão em favelas acossadas pela violência e ter uma Casa da Árvore num lugar desse era como ter uma ilha na qual as crianças podiam, não só expressar o que sentiam com o impacto daquele ambiente hostil, mas também experimentar uma atmosfera mais livre de coerção, de violência, de pressão, de medo... (Benilton Bezerra Junior, 2012, vídeo).

Muitos são os eixos temáticos que podem ser levantados para um debate sobre esse dispositivo, porém, para fins deste estudo, decidimos nos guiar por uma discussão que tem sido bem frequente ao longo dos últimos anos: a dificuldade das crianças e dos adultos de brincarem. Sozinhos ou acompanhados, para adultos ou crianças, a brincadeira tem sido um terreno difícil de trocas e é esse assunto que nos propomos a debater nesta dissertação.

O caso escolhido para tratar aqui é de uma família, moradora de uma favela de Niterói, cidade vizinha ao Rio de Janeiro. Antônia chega, ainda com dois anos, nesse espaço pela primeira vez acompanhada pelo pai, Eduardo. O pequeno corpinho da menina nos parece muito rígido e fechado, e qualquer tentativa de troca com ela, seja por nós adultos ou pelas crianças, lhe causa um grande espanto e rejeição.

No início, ela se aproximava dos brinquedos - todos localizados propositalmente na altura das crianças - e jogava todos eles no chão, num impulso desordenado. O pai, enquanto isso, ficava o tempo todo atrás da menina, recolhendo os brinquedos do chão, tentando minimizar os "danos" causados pelos seus 
impulsos - o olhar dele era de cuidado com o espaço, uma espécie de vergonha pelas atitudes da menina.

Uma das primeiras perguntas de Eduardo para a equipe foi se pais - homens - poderiam frequentar o espaço. Em outras palavras, em um ambiente majoritariamente feminino, ele quis entender sobre suas possibilidades e seu lugar ali. Imediatamente então conta sobre a impossibilidade da mãe de Antônia de estar com ela e acompanhá-la até o serviço por se tratar de uma paciente de saúde mental que, segundo ele, tem muitas dificuldades de cuidar da filha.

Mesmo de um modo meio desconcertado, o pai pôde nos dizer que chegou ali no espaço a partir de uma reflexão de que tinha algo errado com a filha. Ele identificava que, aos dois anos, ela já deveria falar, andar, correr, pular, usar o banheiro sozinha - coisas que ainda não fazia bem. Do seu modo, ele nos aparece buscando ajuda e se encontra bem aberto à nossa disponibilidade de oferecê-la.

Eduardo se espantou com a quantidade de brinquedos que tínhamos naquele espaço, dizendo que não tinha nenhum em casa. Conta-nos que Antônia tampouco convive com outras crianças, não está na creche e pouco sai de casa. Esse ponto nos faz pensar: como será possível a construção do brincar nessa casa?

Winnicott (1975) propõe que o brincar facilita o crescimento e, portanto, a saúde; que o natural da criança é o brincar. Mas que brincar é esse? O olhar dado pela psicanálise em cima do brincar variou ao longo dos anos. Diferente de um olhar kleiniano mais atento para o conteúdo da brincadeira, a proposta winnicottiana é que o ato de brincar seria por si só uma forma de terapia. No caso analisado aqui, será que podemos observar em Antônia um brincar natural e próprio da saúde?

Na teoria da brincadeira, Winnicott (1975) situa um primeiro momento em que o bebê e o objeto estão unidos um com o outro. É nesse encontro, nesse espelhamento, que um primeiro reconhecimento de si se dá. A figura materna é responsável por esse momento inicial, funcionando como esse primeiro objeto de troca - como já mencionado aqui anteriormente.

Na necessidade de justificar a ausência da mãe, o pai narra que ela tem muita dificuldade no cuidado com Antônia, e que ele precisou parar de trabalhar após o nascimento da filha para dar suporte à mulher, que tem diagnóstico de esquizofrenia.

Eduardo traz histórias importantes em torno do nascimento da filha. A família da sua esposa achava que a gravidez era um delírio dela, sem conseguir 
legitimar sua gestação. A menina é a segunda filha da mãe, a mais velha foi separada dela ainda pequena, pois a família alegou que esta não tinha condições de cuidá-la. Após o nascimento da bebê, diziam que ela seria "doente como a mãe", ou teria algum problema físico.

O que esse caso nos mostra é que é possível que as condições psíquicas da mãe de Antônia podem não ter permitido uma troca inicial segura/previsível, pois o que observamos é uma menina que ainda não possui um contorno de si bem delimitado. O que é eu e o que é o outro, para Antônia, ainda é muito confuso e consequentemente, disruptivo. Qualquer toque, ou às vezes até mesmo uma voz externa soa para ela como muito invasivo. Desse modo, buscamos uma comunicação possível entre nós e ela, um espaço comum que seja possível que possamos nos encontrar. Para isso, precisamos de tempo, continuidade e uma construção de um ambiente que pudesse ser confiável para ela.

O pai, Eduardo, acompanhando o movimento da filha, também, ao seu modo, buscava se comunicar com a equipe. Sempre com muitas perguntas e informações, através da palavra, tentava criar um espaço possível de comunicação e troca. Ele indagava constantemente como se brinca. Construindo uma possibilidade de brincadeira para ele, conseguimos construir também, paralelamente, uma possibilidade de brincadeira para Antônia.

O que faz de um ato ser um "brincar" ou não? Para Winnicott, o brincar tem a ver com escolha de palavras, inflexões da voz e senso de humor. É uma possibilidade de ação criativa em relação ao mundo. Como é possível essa criação em um espaço enrijecido? "É através da apercepção criativa, mais do que qualquer outra coisa, que o indivíduo sente que a vida é digna de ser vivida”, diz Winnicott (1975). Do contrário o indivíduo cria uma relação de submissão à realidade externa, onde cabe a ele se ajustar ao mundo - traço que se apresenta em mecanismos psíquicos esquizóides.

A rigidez psíquica materna, apontada na esquizofrenia, permeia as experiências iniciais de troca com Antônia. A mãe possivelmente foi, por todos esses motivos listados, impossibilitada de se colocar em um estado regressivo essencial para o início da vida da filha - impedindo de se criar entre elas uma identificação saudável.

A relação entre a mãe psicótica e o bebê está pautada em uma grande dificuldade da mãe de enxergar aquela criança como real, e de adaptar-se a ela. 
Deste modo, é a criança que se esforça para se adaptar a mãe - o que pode acarretar uma angústia intolerável em ambas (Arruda e Andrietto, 2009). Nesse caso, pela dificuldade de exercer o papel de mãe dedicada comum, ou suficientemente boa, é necessário que outra figura assuma essa função.

Como defende o autor:

O bebê se acostuma com a ideia de que, quando olha, o que é visto (ao invés de seu próprio reflexo) é o rosto da mãe. O rosto da mãe portanto, não é um espelho. Assim a percepção toma o lugar da apercepção, toma o lugar do que poderia ter sido o começo de uma troca significativa com o mundo (...) (Winnicott, 1975, p. 155)

Winnicott (1975) pontua que, apesar dessa dificuldade materna de assumir essa função de espelhamento, alguns bebês não perdem a esperança e estudam o objeto para ver algum significado do que ali poderia estar se pudesse ser sentido. Dessa forma, Antônia precisou criar estratégias de sobrevivência em um ambiente que não funciona como facilitador. Na ausência materna, o pai tenta promover uma experiência especular para a filha apesar de também possuir recursos psíquicos limitados para exercer essa função de maneira suficiente. A busca pela CDA se coloca exatamente no reconhecimento dessas limitações - o que aponta para algum nível de saúde desta família.

A questão do brincar não se refere somente a brincadeiras ou brinquedos, mas sim a possibilidade dos objetos primordiais estabelecerem uma relação de sintonia e espelhamento com o bebê. Entretanto, ao passo que o mundo externo vai se tornando uma realidade para o bebê é necessário que este ambiente tenha objetos concretos que possam servir para a criança se relacionar. Não só objetos, mas principalmente um olhar atento e disponível para criar essa relação.

O primeiro parceiro do brincar para a criança é o cuidador primordial, seguido dos outros adultos à sua volta. A construção de um ambiente facilitador é essencial para que ela possa explorar sua relação de criação a partir de seu próprio corpo, para a partir de aí poder constituir uma troca com o mundo externo. É importante que esse ambiente não ofereça riscos a sua experimentação. Um ambiente seguro para ela se conectar com seu corpo, seus movimentos, seus sentidos, sua intuição e sua liberdade para criar (Machado, 2010). 
O brincar é uma linguagem. No início, é como se o bebê fosse um brinquedo de sua mãe, e com o reacontecer diário das brincadeiras entre os dois, o bebê vai aprendendo essa linguagem (pela experiência vivida) e tomando posse dela - se a mãe o permitir! (Machado, 2010, p. 22).

A casa de Antônia se tratava de um espaço de adultos, sem brinquedos ou brincadeiras. O olhar dos adultos não parecia ser direcionado a ela, mas aos danos que ela causava. Nosso trabalho se pautou na construção de brechas, de possibilidades de quebra desse enrijecimento. Criar espaços em que eles pudessem criar novos mundos.

Em uma casa de adultos, na qual era muito pouco ou nada vista, Antônia usava objetos de uso cotidiano para tentar construir o seu mundo. Como uma vez em que o pai narrou uma história de que ela derrubou uma panela quente em cima dela mesma, em uma tentativa de brincar com a panela. Na falta de um ambiente seguro e de um olhar atento, Antônia se colocava constantemente em situações de risco.

Brincar é viver criativamente no mundo. Ter prazer em brincar é ter prazer em viver. Brincar com espontaneidade é explorar o mundo por intermédio dos objetos. Enquanto usa, manipula, pesquisa e descobre um objeto, a criança chega às suas próprias conclusões sobre o mundo em que vive. Quando puxa, empilha, amassa, desamassa e dá nova forma, a criança transforma, brincando e criando ao mesmo tempo. Poder transformar, dar novas formas a materiais como quiser, propicia à criança instrumentos para o crescimento mais saudável, que a estimula a explorar o mundo de dentro e o mundo de fora dando a eles nova forma, no presente e no futuro, a partir de sua vivência (Machado, 2010, p. 27).

A chegada de Antônia na CDA é marcada por essa passagem: a avidez por um brincar livre, onde existe ao mesmo tempo a exploração, a descoberta e a apreensão da realidade. Ela requer também, com isso, presença e disponibilidade dos adultos para que ela possa fazer suas próprias descobertas.

A Casa da Árvore frequentada por eles funciona todos os dias da semana, alguns dias no horário da manhã e alguns dias à tarde. Com o tempo, Eduardo pôde perceber que a filha ficava melhor - e ele também - em plantões mais vazios, com menos crianças no espaço. Winnicott (1975) sugere que a psicoterapia seria uma superposição de duas áreas do brincar, a da criança e a de outra pessoa... na CDA, temos o adulto, a criança, a psicóloga, a outra criança, o outro adulto... são muitas 
superposições. Talvez para o pai e para filha, naquele momento, eles estivessem precisando de uma dedicação mais exclusiva, possível de suportar.

Winnicott apresenta que "É no brincar, e apenas no brincar, que o indivíduo, criança ou o adulto, pode ser criativo e utilizar sua personalidade integral: e é somente sendo criativo que o indivíduo descobre o seu eu (self)" (1975, p.80). Desse modo, entendemos que ali, naquele espaço, pai e filha buscavam juntos sua capacidade de criação, uma busca pelo eu, em um brincar compartilhado conosco, na Casa da Árvore.

A capacidade de brincar está presente em todos os indivíduos, sejam eles adultos ou crianças. Foi através da possibilidade de Eduardo começar a brincar conosco, construindo uma linguagem comum - em um compartilhamento de culturas - que pudemos constituir uma relação de confiança mútua, criando assim uma experiência de ambiente facilitador para todos. Um espaço potencial, onde é possível vivenciar um brincar criativo junto com a experiência cultural.

Onde há confiança e fidedignidade há também um espaço potencial, espaço que pode tornar-se uma área infinita de separação, e o bebê, a criança, o adolescente e o adulto podem preenchê-la criativamente com o brincar, que, com o tempo, se transforma na fruição da herança cultural. (Winnicott, 1975, p. 150)

Sendo assim, o fracasso da confiança imprime uma restrição da capacidade lúdica, diante das limitações do espaço potencial. Na tentativa de organizar os elementos da herança cultural de Antônia e Eduardo, de modo apropriado, os profissionais da CDA os auxiliam na ampliação desse espaço potencial, de acordo com a capacidade da criança naquele momento.

\section{1}

\section{A Casa da Árvore como ambiente facilitador}

A Casa da Árvore tem uma especificidade de trabalho clínico que é a realização de um atendimento coletivo, onde terapeutas, crianças e famílias usufruem do mesmo espaço durante um certo período de tempo. Esse trabalho nos permite vivenciar mais profundamente as relações, perceber como elas se dão naquele espaço, tentando trazer a realidade vivida ali como um campo de experimentações para o cotidiano. É necessário que haja uma confiança nesse 
espaço para que isso possa ser vivenciado pelas crianças e cuidadores de forma segura.

Uma das primeiras percepções sobre Antônia é que ela tem bastante sensibilidade aos sons do ambiente, bem como se interessa brevemente por diferentes objetos e brinquedos. O interesse aumenta quando esses brinquedos e objetos estão sendo usados por adultos ou crianças. Seu movimento costuma ser de retirar o objeto do outro, apresentando a dificuldade de fazer laços com outras crianças. Por vezes é agressiva, puxando o cabelo ou tentando enfiar o dedo nos olhos destas, o que evidencia uma certa angústia na relação com outras crianças e com alguns objetos, sendo fundamental nossa mediação.

É notória a dificuldade que o pai tem nos cuidados corporais da filha. Em algum momento, pontuou que a troca de fralda é uma responsabilidade da mãe, sem perceber que a menina se encontrava suja. Foi apresentada assim, a possibilidade de lhe ajudar nessa situação, porém ele seguia marcando que preferia não manejar o corpo da filha na sua intimidade.

Corporalmente, Antônia demonstrava ser extremamente desorganizada. O andar instável, seu olhar disperso, a falta de atenção em uma só atividade pareceram mostrar sobre a falta de contorno que lhe permeava. Para ela, o toque do outro era extremamente invasivo, como se qualquer movimento fosse disruptivo.

De início, Eduardo segue a filha por todos os lados e a única interação possível dela é com ele. Com o contato com as outras crianças no espaço, ela se angustia e se isola. Para Antônia, ouvir o "não" é insuportável: grita e se debate fervorosamente.

Essa experiência disruptiva causada pelo "não" soa a nós como uma experiência próxima a uma desintegração. Impedida de garantir sua continuidade de existência por seu ambiente familiar, qualquer quebra de continuidade passa a ser sentida por ela como uma disruptura violenta, como a frustração ou o toque do outro. Antônia não tem recursos possíveis para se ancorar, um fundo materno que lhe assegure continuar existindo. A quebra é sentida como uma agonia profunda, produzindo o choro e o descontrole excessivo.

Winnicott (1951) vai contra o pensamento psicanalítico da época quando aponta para uma fase inicial em que ainda não há um eu constituído. Ele defende que a conquista da unidade é básica para a saúde no amadurecimento pessoal. Inicialmente, se trata de um ser não-integrado que emerge de um estado 
de solidão essencial que permanece - em parte - ao longo da vida no fundo de cada um. A cisão essencial, defendida pelo autor, não é sobre pulsões, mas sim sobre a tendência de abrir-se para o mundo diante do isolamento primordial do ser humano. O objetivo da integração é assim, que esses dois pólos possam coexistir dentro de cada um: a solidão essencial e o encontro com o outro (DIAS, 2003).

Para que essa integração se dê, o bebê depende fundamentalmente de um ambiente facilitador que forneça cuidados suficientemente bons. $\mathrm{O}$ alcance da identidade unitária se dá quando é possível que haja uma separação entre eu e nãoeu, um contorno para si, a construção de limites. Uma falha nesse processo inicial não permite que essa conquista se dê de forma saudável.

Vimos ao longo do primeiro capítulo a importância de um ambiente seguro na chegada do bebê em casa, de uma mãe que possa se colocar em uma posição que quase beira à loucura onde ela possa regredir e se identificar com o bebê permitindo seu desenvolvimento. No cenário narrado da história de Antônia, o período de preocupação materna primária parece não ter sido instaurado e, desse modo, o olhar de sua mãe não pôde permitir que Antônia se integrasse.

Como já apresentado anteriormente, para Winnicott, o bebê nasce em um estado de não-integração, isto é, ainda não possui uma unidade egóica estruturada. Nessa fase, o bebê ainda vivencia experiências de não-diferenciação com o ambiente, principalmente na relação com a mãe. A partir do momento que esta unidade se forma, o indivíduo passa a vivenciar uma alternância entre integração e desintegração, criando assim mecanismos de contorno psíquico que permitem que esta alternância se dê de forma ritmada, fluida, não disruptiva.

Crianças pequenas por exemplo, podem apresentar crises de choro intensas, se debater ou apresentar quaisquer outros sinais de inconsolabilidade; esses movimentos surgem como experiências de desintegração momentânea, no qual indivíduos que já possuem a unidade egóica formada precisam de algum apoio para se reestruturar após alguma situação de ruptura na constância.

Desse modo, Antônia não pode viver uma experiência de desintegração momentânea, pois ainda não possui essa unidade egóica formada. Ela vive, ainda, uma experiência de falha na diferenciação com o mundo a partir da sua não integração egóica. O que acontece no espaço, é nela. O som alto a invade, o outro a invade, o que está fora se mistura com que está dentro - ela não consegue fazer 
essa distinção. Não consegue criar um contorno psíquico para si mesma, uma proteção, o que a faz permanecer o tempo todo em estado de alerta.

É importante ressaltar que não se trata de um raciocínio lógico: se a mãe é deprimida, o filho também o é. Partimos do princípio de que mãe e bebê estão jamais sozinhos, existem outras pessoas que compõem o ambiente familiar. O pai da criança, avós, avôs, ou outros familiares também fazem parte desta estrutura familiar. Se o bebê sofre da psicopatologia materna é porque todos os terceiros que deveriam ou poderiam ajudá-lo, também falharam.

Desse modo, percebendo as dificuldades da filha, Eduardo busca um auxílio profissional para lhe amparar nos seus cuidados. A Casa da Árvore se torna um espaço onde pai e filha buscam, mais uma vez, essa tentativa de integração e organização psíquica. O pai tenta assumir essa figura de cuidado, de modo que a menina possa se sentir segura o suficiente na presença dele podendo assim se desenvolver.

A partir do momento em que Eduardo consegue se sintonizar com a filha e interagir com ela, a possibilidade de construção da subjetividade dela se permite acontecer. Ele pode olhar para ela, e quando ela o olha de volta, pode ver a si mesma. É através do compartilhamento de afetos que essa troca pode acontecer. Para Golse (2003), brincar permite a descoberta do outro, um outro que possa atuar como um espelho, parecido com ele, mas também não-parecido. Esse espaço de brincar precisa da liberdade que vai se criar, ou não, para que se deem os encontros e para que haja efeitos deles.

Ainda segundo o autor, só é possível brincar-junto se existe uma experiência de prazer compartilhado. A narratividade do adulto só faz sentido para a criança se ele experimenta prazer nessa atividade, criando um fundo, um clima emocional, de disponibilidade para o compartilhamento de afetos de prazer. Construir com o pai uma narrativa no brincar, criar com ele essa possibilidade de fazê-lo se torna ferramenta chave para que ele possa construir com ela esse compartilhamento.

Em outras palavras, foi preciso criar com o pai uma possibilidade de ele mesmo brincar. A partir de um jogo de cartas, Eduardo pode se aproximar da equipe. Juntos, apresentamos as regras e fomos, semana a semana, o ensinando a jogar. A partir dessa troca nós-ele, ele foi criando ferramentas para a troca pai-filha.

Um dos primeiros passos dessas conquistas foi estimulá-lo e acompanhá-lo na troca de fralda da filha. Durante o cuidado com a higiene íntima da menina, 
pudemos falar sobre a importância de um contato com esse corpo, em uma tentativa de holding, sustentação para um corpinho ainda não-integrado.

\section{2 \\ O encontro com 0 adulto cuidador}

Golse (2002) defende que os bebês exigem muito de nós, mas que existem três fatores essenciais: maleabilidade, narratividade e uma certa qualidade de nossa bissexualidade.

O termo objetos maleáveis foi cunhado por Marion Milner (apud Golse, 2002) no que diz sobre as qualidades do adulto que permitem a criança se diferenciar, se destacar, dele mesmo. Winnicott (1951) apresenta essa ideia quando propõe os objetos transicionais, que trabalham a criatividade do bebê no que tange a inventar certos objetos (chamados de transicionais) que permitem que o separem da mãe. E é preciso que esta seja uma separação gradual, sem que haja uma grande ruptura.

Não se trata do objeto em si, mas na relação que o bebê cria com ele. É um objeto que não se sabe ao certo qual é a fronteira entre ele e nossa pele, garantindo uma certa continuidade. Quando o objeto é deixado, ele não permanece colado pode-se criar um alívio nos opostos fusão com o objeto e des-fusão, seguidos por uma re-fusão e uma des-re-fusão. Nesse brincar com o objeto, o bebê vai descobrindo, e sentindo, as diferenças entre o que é interno e o que é externo.

Desse modo, é preciso que o adulto cuidador exerça essa função. De alguém que permite a troca quase fusional e a separação sem uma cola, isto é, permitindo que o outro possa estar também sozinho. Essa separação é marcada por um traço, uma impressão que fica de si no outro - um vestígio de nossa presença. Em seguida, outros objetos poderão ir tomando esse lugar, como um urso, um paninho, como sugere Winnicott quando discorre sobre os objetos transicionais.

Golse faz uma relação entre os dispositivos terapêuticos com bebês surgindo como um terceiro maleável, de dupla inscrição, que permitem o bebê a se diferenciar. A qual iremos nos deter mais à frente.

A narração permite o bebê de construir uma relação entre o "estar junto" e o "fazer junto". O encontro do adulto com o bebê é esse espaço de narração - um espaço interativo que é absolutamente específico. Nessa troca, o adulto chega com 
os traços de quem é e do bebê que fora outrora, mas de um modo diferente em cada vez que chega para o encontro.

Então cada um, o bebê e o adulto, conta uma história muito antiga, e de fato a única possibilidade de liberdade para o bebê é co-escrever, coconstruir com o adulto uma terceira história que dá conta desse momento que é uma nova história, com um certo grau de liberdade. E as terapias conjuntas, qualquer que seja o dispositivo que tenhamos, o fazemos com o objetivo principal de reconduzir o jogo, de reconduzir a liberdade na escritura dessa terceira história que, senão, será bloqueada de um lado ou de outro (GOLSE, 2002, p.38/39).

O papel da qualidade da bissexualidade psíquica se coloca no nível dos laços que se tecem em torno da criança. Para o bebê, é necessário que exista, em nível relacional, afetivo, algo do maternal, feminino, do holding e do handling, mas também é algo com um aspecto mais paternal, masculino, que introduz a lei - que autoriza e interdita.

Didier Houzel afirma que cada vez que um bebê está em relação com os adultos ou com um dispositivo terapêutico cuja bissexualidade psíquica está mal integrada, então o bebê vai atacar o sistema até torná-lo muito vulnerável, muito frágil. Se, ao contrário, encontra pessoas e laços entre as pessoas cuja bissexualidade esteja suficientemente integrada, que tenham uma dosagem correta da continência e limitação, então, ao contrário, o bebê vai se tornar sustentado em sua atividade de construção e de ligação pessoal (Golse, 2002, p.39)

Um pequeno exemplo clínico é quando jogamos um jogo com as crianças. Com algumas, é importante que tenhamos ali bem estabelecidas e demarcadas as leis, as regras, enquanto com outras é importante dar um espaço para burlá-las criando ali um afrouxamento afetivo que acolhe, dá um suporte.

No caso de Antônia, seria importante que o pai pudesse usar da função maternal naquele cuidado com ela, enquanto nossa atuação se tratava por permitir, legitimar, essa existência. A função do dispositivo terapêutico proposto por Golse, reiterado por nós, é ajudar o bebê a interiorizar um enquadre psíquico que the permita construir envelopes psíquicos que ainda não estão colocados. Isso se faz a partir da recondução de um terceiro - maleável, narrativo, bissexuado -, um terceiro continente. Não se trata ainda de um terceiro edípico, castrador, o primeiro terceiro da criança é um primeiro que contextualiza a mãe e o bebê, que promove a função de continência, garantindo uma boa fronteira entre o dentro e o fora. 
Todo dispositivo terapêutico digno deste nome deve ter um aspecto continente, que reenvia nossos estereótipos um pouco mais ao maternal e ao feminino, o holding, o handling, e também um aspecto mais regulador, mais limitante, que reenvia nossos estereótipos ao plano paternal, mais masculino, à lei, ao que legisla, regula, ao que autoriza e ao que interdita (Golse, 2002, p.39)

Como já apresentado no capítulo 1, o holding se caracteriza pelo ato de segurar, fazendo referência a um suporte físico e psíquico do seu objeto cuidador. O holding é o que garante ao bebê a experiência de confiança e previsibilidade. São um conjunto de comportamentos, de cuidados, que passam pelas necessidades biológicas - como alimentar e manter o bebê limpo - e vão até a sensação de acolhimento, segurança psíquica.

O handling está ligado a um manejo, a uma troca corporal de pele com pele enquanto se dão os cuidados básicos do bebê. Auxilia o bebê a desenvolver o sentimento de estar dentro do próprio corpo -formar as bordas psíquicas do seu corpo, a separação entre eu-outro. O par holding-handling assim, auxiliam o bebê no seu desenvolvimento emocional primitivo, no processo de integração corporal, personalização e realização. E é esse processo de construção de intersubjetividade que tratamos aqui pelo brincar.

Só é possível brincar com o outro se este puder ser percebido como outro. Roussillon (2006) pontua que o primeiro outro da criança só pode ser um outro "especular e empático", homomórfico, a partir do momento em que é suficientemente parecido, porém um pouco distinto. $\mathrm{O}$ autor aponta para a ideia de que é necessário que exista um compartilhamento de afetos de prazer nesse encontro, para que o bebê possa vivenciar uma experiência de intersubjetividade, onde o objeto se propõe, mas não cole nele. Ele situa:

Entre mãe e bebê, o vetor do encontro, o que condiciona o prazer da relação e talvez até a composição psíquica do próprio prazer, é o processo pelo qual um e outro dos dois parceiros se constitui como espelho e, portanto, duplo do outro. (Roussillon, 2006, p.8)

Segundo o autor, o bebê "percebe", desde às primeiras horas, a mãe que é capaz de "construir", isto é, é alguém diferenciado dele com quem se coloca um vínculo de apego, de um encontro com um outro no qual ele terá de se reconhecer, um "duplo" dele mesmo. O duplo deve ser suficientemente ele mesmo - no qual 
ele se reconhece - e, ao mesmo tempo, suficientemente o "outro" - do qual ele se diferencia. É preciso que o objeto primordial seja capaz de exercer, no encontro, essas duas funções para que a criança possa assegurar sua existência e capacidade de se desenvolver.

No caso trabalhado aqui, foi necessário criar um espaço possível de encontro entre o pai - adulto cuidador - e a filha, de modo que essa troca possa se dar de forma prazerosa. Eduardo pôde, gradualmente, perceber a filha nas suas especificidades e necessidades, enquanto Antônia, pôde se sentir segura e amparada por aquela figura, sendo reconhecida e singular. Foi necessária uma aproximação físico-corporal - mediada e estimulada por um profissional - para que os dois pudessem se olhar, se reconhecer e se diferenciar.

Como proposto por Golse (2002), é através de uma relação com os primeiros objetos relacionais que a criança pode se diferenciar de maneira gradual e não traumática do objeto. Para isso, é necessário que o objeto assuma um caráter de maleabilidade, que seria a capacidade do objeto de se deixar marcar pelo sujeito que o utiliza, permitindo o sujeito a deixar impressões, vestígios das relações que são experimentadas por ele com esse objeto. São certas características próprias ao sujeito que garantem sua capacidade de "separabilidade".

\section{3 \\ O brincar como processo}

A cena de sessões seguintes se coloca em uma piscina de bolinhas, que tínhamos no nosso espaço, que ficava no centro de quatro túneis. Com um buraco em cima da piscina, era possível que o adulto colocasse a criança direto no centro - ou retirá-la dali se necessário. Certo dia, Antônia se interessou pelo túnel e quis entrar. Com muita dificuldade, não pode fazê-lo sozinha e chorou. Eduardo percebeu a angústia da filha, pegou-a no colo e colocou-a no centro, com as bolinhas. Mas a menina seguiu chorando. Uma de nós psicólogas pode se aproximar e narrar a cena "olha, acho que não era bem isso que A. queria...". Eduardo percebeu o que acontecia e a colocou novamente do lado de fora. Conversou com ela e tentou estimulá-la a entrar no túnel sozinha. Ao final, colocou um celular no meio dos túneis, como uma "isca". Funcionou, Antônia pôde, com a ajuda do pai entrar pelo túnel. Ela sabia que ele estava ali a acompanhando. 
Essa cena conta-nos de um pai que primeiramente quer pular os obstáculos - o túnel - para alcançar o objetivo final - chegar até as bolinhas. A menina demonstra que não é sobre isso. Com a ajuda da psicóloga, ele pôde perceber que não se trata de alcançar um objetivo, se trata de poder passar pelo processo. Passar por um túnel é difícil para Antônia, pois ela não sabe o que a espera do outro lado. Ela precisa de alguém que esteja do lado dela lhe assegurando de que seguirá existindo.

Essa virada de chave aponta para um momento crucial na relação dos dois. O pai não precisa mais fazer POR ela, ele pode fazer COM ela. Ele pode sair de uma posição de ego auxiliar, passando a ser, gradativamente, o outro. Em uma analogia à cena vivenciada no plantão, podemos observar um adulto que se permite se tornar um "pano de fundo" que lhe assegura a possibilidade de ser.

O brincar na primeira infância tem uma função de integrar, personalizar e essa função só pode ser conquistada no encontro com o outro. A relação (re)construída entre pai e filha permitiu uma nova possibilidade de vivenciar essa experiência primária de relação com o objeto. A desorganização que vimos na chegada de Antônia na Casa da Árvore já não se apresentava mais, ela foi, com o tempo, ganhando força e contorno próprio. Foi impressionante perceber como ela cresceu, literalmente, com todos esses ganhos.

Winnicott (1975) aponta que o brincar existe inserido em um espaço e um tempo. Desde o início, as primeiras relações entre mãe e bebê marcam a possibilidade da mãe apresentar o mundo para o bebê de modo que, a princípio, o bebê entenda que aquilo fora criado por ele em uma ilusão de onipotência. Desse modo, ele começa a relacionar-se com a realidade "externa" - do ponto de vista do observador - pela via da criatividade e não da submissão. Os fenômenos transicionais, conceituados pelo autor, marcam um meio do caminho, entre a sensação de ilusão de onipotência da realidade subjetivamente percebida, para a percepção de um mundo externo, da realidade objetivamente percebida.

A possibilidade de criar um mundo com o pai, senti-lo presente e previsível, permite que Antônia adentre por uma via onde a criatividade é possível advir. Ela passa a poder observar esse mundo de outro modo, permitindo que ela passe a perceber o que está dentro e o que está fora, nesse espaço intermediário proposto por Winnicott (1975) como espaço potencial. Reconhecer o pai como um objeto não-eu foi o primeiro passo para essa conquista. 
Com o passar do tempo, Antônia passou a chegar de modo diferente na Casa. Nos permitiu começar a fazer contato com ela, liberando o pai para esse contato também. Pudemos entender um pouco mais da história dela na conversa com o pai, nos aproximar dele, ouvir suas dificuldades. Através do jogo de cartas e na possibilidade de escuta, ele pôde se vincular a uma psicóloga, enquanto a filha se vinculava à outra. Antônia vivia situações longe do pai, e na frustração, voltava até ele, que a amparava.

O trabalho com a menina exige que estejamos sempre atentas acompanhando seu movimento, e ajudando-a a estabelecer os limites do espaço, do corpo dela e do corpo do outro, de diferenciação dos objetos, da possibilidade de trocar e compartilhar, de estimular que ela fale aquilo que deseja para nós, emprestando-a algumas palavras que já começa a repetir e fazer uso. Nosso brincar envolve as possibilidades de localização de seu corpo no espaço, introduzindo os objetos ainda de maneira muito primordial.

Dentro-fora, cima-baixo, abre-fecha,... Repetidamente ela busca brincadeiras envolvendo pares opostos. Nesse jogo, ela passa a tentar identificar e nomear aquilo que está dentro ou fora. Construímos ali um espaço seguro, que ela podia confiar. Que estava sempre ali, todas as vezes que ela - e o pai - voltavam.

Nessa conquista de confiança pudemos começar a perceber alguns avanços. A aquisição cada vez mais notável era a da fala. A partir de um certo dia, ao invés de chegar desorganizada, chorosa, com dificuldades de entrar na Casa, ela pode localizar sua angústia dizendo que sua mãe havia saído. E a cada encontro chegava repetindo essa constatação. Primeiro repetidas vezes, e após algum tempo, apenas uma notícia na sua chegada. Desse modo, ela pode situar onde está sua mãe e onde está ela mesma. Perguntávamos assim onde estava o papai, e ela sorria ao localizálo.

Uma outra cena que propomos trazer aqui é a de um dia que uma das psicólogas se deslocou para uma posição em cima de uma escada dupla, no alto da sala. Ali de cima, pôde observar Antônia brincando, subindo e descendo da cadeira, abrindo e fechando a gaveta - acompanhada de uma psicóloga que nomeava isso tudo para ela. O pai jogava cartas na mesa com outra psicóloga, contando um pouco sobre sua vida e dificuldades.

Eventualmente, a menina se deslocava e ia até o pai. Ele parava o que estava fazendo, conversava com ela e a menina voltava para a sua brincadeira. Não era 
mais de forma afoita. A menina sabia a quem recorrer quando precisasse. Ela confiava nele, e ele confiava nela - não precisava mais ficar preocupado atrás dela o tempo inteiro. De cima, eu narrava esses encontros e desencontros. Sobre a possibilidade de estar junto e separado, e da casa da árvore também poder criar esse espaço possível do "entre".

$\mathrm{O}$ amadurecimento proporciona a possibilidade de criar mundos e transitar entre eles. O espaço potencial surge como uma terceira área da experiência, uma área que estará disponível para criação e o exercício da capacidade de brincar e simbolizar, se alargando para, ao longo da vida, a vivência da arte e a cultura em geral. Winnicott pontua que esse espaço não está nem dentro nem fora, é um espaço próprio do bebê, no qual ele é, ele mesmo, esse espaço.

O bebê, portanto, não transita de um objeto a outro, mas de um mundo a outro. Melhor: sendo ele mesmo esse espaço, deve-se dizer que ele transita, nele mesmo, de um a outro sentido de realidade, como mundos de seu ser, podendo habitar nos vários mundos por ele criados, mundos em que novos objetos podem aparecer. (DIAS, 2003, p.239)

Só é possível viver essa experiência se o bebê estiver amparado em uma relação de troca e confiança. O espaço potencial, proposto por Winnicott, é um espaço de confiança entre mãe e bebê, onde ele pode viver essa separação sem se separar. É aí onde a criatividade pode surgir, sua própria capacidade de criar mundos. E só assim é possível seguir no seu processo de subjetivação.

No caso apresentado aqui, a Casa da Árvore funciona como um espaço de contenção da desorganização parental e da criança. Na dificuldade da mãe de construir uma relação saudável, que permita o desenvolvimento pleno da criança, foi necessária sua retirada para que outro possa exercer essa função. A função terapêutica aqui era dispor de um lugar seguro e confiável, que legitimasse a função materna desenvolvida pelo pai, para construir, junto com os dois uma nova possibilidade de desenvolvimento emocional.

O psicanalista Victor Guerra aponta:

O analista deve funcionar como "tradutor", "ponte" entre a experiência sensorial e a representacional, entre o mundo infantil e o mundo adulto, e sua ferramenta é a palavra, a metaforização transmodal, em sua disposição interior para a escuta que se expressaria em: uma disposição corporal flutuante e uma disposição mental lúdica. (GUERRA, 2018, p. 185) 
Com isso, é possível dizer que esse espaço criado pela Casa da Árvore permite que alguém faça essa função de “ponte' que, junto de um trabalho pela palavra, permite que Antônia possa metaforizar e simbolizar os processos que acontecem dentro dela. Junto ao pai, co-construímos essa possibilidade de relação entre eles e nós. Ajudá-los a enxergar esse (des)encontro intersubjetivo, como usa o autor, permite que ela crie essa possibilidade de, gradativamente, se enxergar como diferente do outro.

Restaurar um ritmo perdido entre eles, através das brincadeiras, na presença do pai traz à tona uma experiência de contenção de ansiedades, gera um prazer compartilhado e a integração de suas múltiplas sensorialidades - permitindo-a adentrar no mundo possível das simbolizações. Só é possível viver a falta de um objeto se ele estiver presente. O movimento dela de ir-e-vir no pai se torna assim, uma marca de que essa presença se dá ali, diante desse novo cenário.

Para Eduardo, o processo era de reconhecer a menina que era sua filha, para além daquele rótulo que fora criado para ela desde a barriga. Ele buscava nossa afirmação quando supunha que ela não era a criança doente que lhe diziam que seria. Essa ferida que acompanhava a família acompanha Antônia desde seu planejamento. Apesar de ter sido muito planejada e desejada, era difícil para todos descolá-la disso. Estar ali e enxergá-la por quem era e não por quem poderia ser foi um processo importante de mudança de perspectiva que lhe permitiu outras possibilidades de subjetivação.

\section{4}

\section{Tipos de brincar: o brincar auto-subjetivo, o brincar interativo e o brincar intra-subjetivo}

O psicanalista René Roussillon (2006) define três tipos de brincar, como etapas do desenvolvimento infantil: o brincar auto subjetivo, o brincar interativo e o brincar intra-subjetivo. O brincar auto-subjetivo se refere a atividades desenvolvidas pelos bebês que lhes permitem sentir, existir e assegurar seu sentimento de continuidade de existência. Todas as atividades auto-centradas que vão, progressivamente, fazendo a passagem da auto-sensorialidade para o autoerotismo, que inclui sempre uma representação de objeto ausente ou faltante - como no ato de chupar o dedo aliada ao pensamento do seio/mamadeira (alucinação primitiva), enquanto que na auto-sensorialidade não faz, necessariamente, 
referência a um objeto (GOLSE, 2003). Em outras palavras, é a partir de uma presença do objeto que se constrói uma possibilidade de sua falta.

Se fizermos uma analogia à cena da troca de fralda de Antônia, podemos pensar esse como um momento inicial que garante a ela sua existência. Através de uma possibilidade de olhar para ela, ela se permite retomar uma cena tão primária e vivenciá-la com o pai de forma menos traumática que outrora. O trabalho realizado ali era construir com ele a possibilidade dele ser capaz de tocá-la, segurála e contê-la, legitimando sua paternidade e essa função materna que exerce na vida da filha. Ele existe ali para a filha, ele consegue estar presente.

O momento do brincar de construção da sua transicionalidade que permite aceder à intersubjetividade, que prepara a criança para o evento da linguagem e das pré-simbolizações é nomeado por Roussillon como o brincar interativo. Seriam todos os comportamentos do brincar que se inscrevem no seio de diferentes processos de triangulação precoce.

Trata-se de um momento em que a criança é capaz de se oferecer como objeto pulsional a outro. Nesse ponto, a criança ainda não tem uma consciência clara de que está brincando, porém teria uma certa capacidade de analisar as sequências de reação do outro e de detectar os desvios pelo ritmo esperado. Desse modo, o bebê pode começar a fabricar suas representações de interações generalizadas (Golse, 2002).

Para que a criança possa usar o objeto - o objeto tem que ser real, no sentido de fazer parte de uma realidade compartilhada e não um feixe de projeções. As características do objeto - natureza e comportamento - estão presentes nesse caso. O autor grifa sobre a importância da presença do objeto para que isso ocorra.

O bebê vive a experiência de criar o objeto, mesmo considerando que o objeto já estava ali à espera de ser criado, e de se tornar o objeto investido. Para usar um objeto, o bebê precisa ter desenvolvido essa capacidade, faz parte de um processo de amadurecimento. Na teoria de Winnicott, enquanto o sujeito não destrói o objeto subjetivo (feixe de projeções), a destruição surge e se torna característica principal, na medida que se torna objetivamente percebido, ele tem autonomia e pertence a uma realidade compartilhada. $\mathrm{O}$ sujeito coloca o objeto fora da área de seu controle onipotente, e se ele é externo então o sujeito pode destruí-lo. Se o objeto sobrevive é aí que o sujeito pode usá-lo. 
Roussillon (1960) aponta que a primeira experiência que uma criança pequena faz de mundo é marcada pelo objeto transicional e os fenômenos transicionais, a experiência da primeira posse de um objeto não-eu. Nesse momento, a criança apreende um objeto que não se localiza nem dentro nem fora, mas no limite de ambos. "Para ser criado, o objeto deve ser encontrado, isto é, posto ali pelo ambiente" (p. 85). Sendo assim, a experiência só se constitui na presença do objeto e não na sua ausência. É preciso que a mãe apresente o seio ao bebê no momento e lugar exatos para que este se sinta capaz de criá-lo, tendo uma experiência paradoxal ilusória.

Essa atividade psíquica, que Winnicott diz ser a primeira atividade psíquica, não pode aparecer, ela própria, sem uma dupla condição: que o objeto, que será o objeto da retomada, seja colocado ali pelo que está em volta da criança, e que o objeto eleito seja respeitado pela mãe, isto é, que esta não coloque a criança na alternativa de ter que decidir se esse objeto vem de "dentro" ou de "fora" (Roussillon, 1960, p. 87).

A atividade mental consiste no deslocamento (derivação) dessa primeira experiência para originar o espaço psíquico do jogo. Sendo assim, podemos compreender que a experiência paradoxal da transicionalidade se ancora nessa experiência primeira de ilusão que é apoiada nos cuidados corporais, se desviando, ele próprio, para um processo apoiado no ambiente.

$\mathrm{Na}$ experiência paradoxal da transicionalidade, o objeto é ao mesmo tempo criado subjetivamente pelo bebê e encontrado objetivamente por ele, sendo o objeto o símbolo da união desses dois pontos de vista. É necessário que haja uma certa homomorfia (semelhança de forma com estruturas fundamentalmente diferente) para que o sentido do real se constitua. Roussillon (2006) aponta aqui que é nesse momento, de transicionalidade, que a criança acaba de construir um representante interno/externo que permita a saída do momento inicial em "duplo". O desvio de expectativas nesse momento pode acarretar uma situação traumática onde os processos transicionais não conseguem se constituir ou assegurar sua função de representante neste processo de simbolização primária.

Para o autor, os processos de simbolização primária estariam em um campo que se apoia na qualidade de presença do objeto, das sensações e percepções decorrentes das relações interpessoais, enquanto que os processos de simbolização secundária se fundam sobre a ausência e sobre o trabalho de luto da perda do objeto. 
É preciso que o processo de simbolização seja compartilhado para ser integrado e apropriado pelo sujeito.

O aprofundamento dessa experiência de diferenciação intrapsíquica estaria marcado em um brincar intra-subjetivo. Ele está relacionado à capacidade de estar só ao lado de um adulto, como assegura Winnicott, em uma brincadeira livre onde o adulto pode servir de continente para o desenvolvimento da atividade; se trata de um momento de experimentações psíquicas onde a criança se apoia no encontro anterior com o adulto, simbolizando ou pré-simbolizando estes restos mnésicos.

No texto "A capacidade para estar-só" (1958), Winnicott aponta que, após passado o estágio de transicionalidade, o bebê é capaz de ficar sozinho na presença de alguém. Esse movimento é algo que pode ocorrer mesmo em fases mais precoces e o ego do indivíduo ainda se apoia ao ego auxiliar materno, porém, posteriormente, esse ego auxiliar materno é introjetado e o bebê passa a ser capaz de ficar só sem o apoio da mãe, atingindo um estágio de construção do "eu sou”. Estar-só é uma continuidade do "eu sou", pois depende da percepção da criança da existência contínua de uma mãe disponível.

A partir da suposição de que a pessoa que ama (que é digna de confiança e por isso lhe dá segurança) está disponível para ser lembrada, e assim presente mesmo na sua ausência, a criança está se preparando para permitir e fruir uma superposição de duas áreas da brincadeira. Primeiramente, a mãe é quem brinca com o bebê, se ajustando às suas necessidades, posteriormente, a criança introduz o seu próprio brincar na relação com outra criança, encarando a introdução de ideias que não lhe são próprias, caminhando para o brincar conjunto num relacionamento.

Roussillon propõe que a função dos objetos primordiais é fortalecer as experiências primeiras na medida que o objeto ofereça possibilidades. A abertura para o mundo se dá na confiança da continuidade de existência, do interesse que o outro provoca.

A capacidade de estar-só, proposta por Winnicott, seria uma experiência de solidão paradoxal onde a mãe está duplamente presente, como fundo silencioso real - mãe-ambiente - e também no jogo autoerótico da criança - presente como objeto. Nessa experiência, a criança interioriza o "fundo materno" silencioso graças ao desenvolvimento desse jogo com as representações do objeto (tolerado e aceito pela 
mãe). Nesse formato, a criança passa a elaborar a ausência da mãe, onde se efetua o primeiro descolamento das representações internas com o objeto real.

Acontece em três momentos: i) a criança acredita estar só, sendo capaz de criar os cuidados maternos quando necessários - ilusão de solidão; ii) a criança "esquece" que não está só - a realidade externa (mãe-ambiente) fase isomorfa a realidade interna - enquanto o espaço transicional se internaliza por intermédio do autoerotismo e dos processos que nele se precipitam - um primeiro esboço da fantasmática se efetua; iii) a capacidade de deixar a mãe sozinha na presença do outro, o pai - cena primária posteriormente problematizada no Édipo e na castração (Roussillon, 2006, p. 90).

E o que envolve esse terceiro tempo do brincar? Passada a fase de repetir incessantemente palavras emprestadas pelos outros, Antônia pode passar a criar suas próprias. Sua boca, antes preenchida por chupeta, ou por gritos desconcertantes, agora se encontrava cheia de palavras.

Todo esse processo de atendimento a essa família durou cerca de dois anos. Foi um cuidado contínuo, múltiplo e muito rico. O trabalho clínico realizado com a dupla pai-filha fora essencial nesse processo. Foi preciso uni-los para poder, só assim, separá-los. Sem qualquer outro espaço possível de troca com outras crianças, ainda sem creche, a Casa da Árvore se configurou como o único lugar possível para que eles vivessem essa separação, permitindo a entrada de novos objetos e pessoas na vida dessa família.

Como a apresentação sequencial dos estágios do amadurecimento e o próprio termo 'estágio' podem induzir a ideia de etapas estanques, cada uma sucedendo à outra, é preciso salientar aqui que, a despeito de ser assim apresentado, o processo não é linear. (...) amadurecer inclui a possibilidade de regredir a cada vez que a vida exige um descanso, em momentos de sobrecarga e tensão, ou para retomar pontos perdidos. (DIAS, 2003, p.101)

Todo esse processo de amadurecimento emocional de Antônia não se deu de forma tão clara e linear. Muito se passou no meio desses atendimentos com ela. O que é importante ser levantado aqui é a importância da figura paterna durante todo esse acolhimento.

A impossibilidade dos adultos do entorno de Antônia de regredirem até o estágio da infância, lhe proporcionando uma experiência de desamparo e de ausência de uma continuidade de existência, fez com que seu desenvolvimento 
emocional estagnasse em um ponto em que seu eu não tinha como advir. Pai, mãe e filha estavam paralisados em algum ponto que não conseguiam seguir sozinhos. A tentativa de buscar ajuda foi um passo muito importante para essa desparalisação.

$\mathrm{O}$ adulto traz na interação todas às capacidades de sintonização e harmonização dos afetos, toda a sua história (principalmente a infantil) e todo o peso de sua personalidade, mas também todo o impacto que esse bebê ocupa no seio do seu mundo representacional (o que marca que cada adulto evidentemente não cuida da mesma maneira de cada criança (Golse, 2002, p. 54).

Ao encontrar a Casa da Árvore, um espaço de atendimento terapêutico para crianças e famílias, Eduardo pode viver sua própria criança interna, se permitindo começar a brincar. E essa possibilidade permitiu que juntos pudessem encontrar espaços possíveis para narratividade e a liberdade no desenvolvimento de Antônia. É nesse encontro em que o brincar em cada um tenta modificar o outro, aceitando modificar o outro em si mesmo.

Toda essa dissertação se volta para esse ponto primordial: como é para uma criança desenvolver uma capacidade de brincar em uma casa onde os adultos não a tem, como é possível fazer um trabalho com essa criança se não é realizado um trabalho com os pais? Para responder essas perguntas, se torna essencial um olhar mais atento sobre os pais e a importância da sua presença no setting, para construir com eles a possibilidade de uma nova ordem familiar. 


\section{4 \\ O trabalho com a família}

O trabalho realizado na ONG Casa da Árvore propõe que todos os agentes de cuidados da criança estejam juntos em um mesmo espaço - pais, mães, crianças, tios, avós e psicólogas compartilhando o mesmo lugar paralelamente. Desse modo, é possível que possamos tratar não apenas das crianças como de todos aqueles que estão no entorno. Atuamos ali como mediadoras de determinadas situações, estimulando, questionando e buscando entender junto com as famílias suas dinâmicas.

Para além de ajudar a criança a se organizar e construir conosco a possibilidade de brincar, buscamos encontrar no adulto uma brecha para essa brincadeira surgir, dando uma visibilidade maior para esses pequenos grandes momentos. Discutir sobre a importância do brincar é estar com um olhar atento para aquilo que a criança quer e precisa. Para seus medos e inseguranças.

Como é possível realizar esse trabalho em um espaço de atendimento individual tradicional? $\mathrm{O}$ manejo com as famílias, a dinâmica da presença e da ausência no consultório, a disponibilidade de cada um dos agentes de cuidados diz muito sobre a história dessas famílias, assim como a possibilidade de cada um para a brincadeira.

O brincar da criança, como sugerido por Freud ainda em 1908, é marcado exatamente por essas possibilidades de criação do seu próprio mundo, onde ele reajusta os elementos do real de uma forma que lhe agrade. Se torna ativo em um circuito que é passivo, tornando uma realidade desagradável em algo passível de ser elaborado, através do brincar.

O brincar, para Freud, é projetar no futuro o desejo de ser grande, adulto. A atividade lúdica da criança gera uma excitação, uma satisfação pulsional. O brincar funciona como uma descarga pulsional infantil e não são apenas as crianças que precisam dessa descarga. Como Freud (1908) pontua, os adultos também precisam dessa satisfação pulsional que se transforma ao longo da vida. Alguns dos seus desejos ocultos surgem no consciente sob formato de devaneios. A diferença é que, 
nos adultos, tais desejos se tornam segredos que não podem ser compartilhados. São encobertos pela vergonha e os guardam dentro de si, sem poder descarregá-los.

Segundo o autor, ao brincar, a criança traz elementos de sua realidade para produzir seu novo mundo, de modo que esse reajuste lhe garanta a satisfação de seus desejos. Mesmo com todo seu investimento emocional, ela é capaz de saber distingui-lo da realidade. Fazendo uma analogia com os artistas, o autor aponta que, ao fantasiar uma história, o escritor criativo permite criar diversas situações que geram excitações em outras pessoas, que compartilham com ele desse prazer escondido. Porém, se trata de uma descarga através da arte, de modo que, se fossem do campo da realidade, seriam extremamente penosas.

A experiência da brincadeira gera na criança uma sensação de prazer, de excitação. Ainda que amparada na realidade, a criança se permite viver situações incomuns de seu cotidiano onde pode ser quem quiser e agir como quiser. $\mathrm{O}$ autor pontua:

O brincar da criança é determinado por desejos: de fato, por um único desejo - que auxilia o seu desenvolvimento -, o desejo de ser grande e adulto. A criança está sempre brincando 'de adulto', imitando em seus jogos aquilo que conhece da vida dos mais velhos. Ela não tem motivos para ocultar esse desejo. Já com o adulto o caso é diferente. Por um lado, sabe que dele se espera que não continue a brincar ou a fantasiar, mas que atue no mundo real; por outro lado, alguns dos desejos que provocaram suas fantasias são de tal gênero que é essencial ocultá-las. Assim, o adulto envergonha-se de suas fantasias por serem infantis e proibidas (Freud, 1908, p.137).

A conexão do brincar com a realidade é o que diferencia o brincar da fantasia. Ao crescer, o prazer que antes era gerado pelo brincar se substitui pelas fantasias - construções psíquicas no formato de devaneios. Desse modo, o autor aponta que toda fantasia é a realização de um desejo, uma correção da realidade insatisfatória, mas que não pode ser externalizada pelo adulto, que se envergonha e a reprime.

$\mathrm{O}$ autor sugere que a dificuldade do brincar adulto vem desse segredo, dessa repressão própria de tornar seus desejos visíveis para o outro - mesmo quando o outro é seu próprio filho. A dificuldade de se mostrar sensível, como alguém passível de perda, surge como um grande impeditivo nessa possibilidade de brincar. 


\section{1}

\section{A dificuldade do adulto de brincar: uma atualização da infância}

Ocupar-se do bebê é decididamente aceitar ser tocado nas partes mais vulneráveis, é deixar-se reativar nas angústias mais primitivas (dizemos arcaicas, mas pode-se dizer como quiser), nas posições depressivas primárias. Se não aceitamos nos deixar tocar aí, não podemos partilhar o que quer que seja com o bebê, então não podemos compreendê-lo no sentido verdadeiramente etimológico que é "tomar junto" o que existe do outro e o que ressoa em você (Golse, 2002, p.28).

Este trecho escrito por Bernard Golse aponta como o infantil do adulto é atualizado quando ele tem um filho. $\mathrm{O}$ bebê tem necessidade que o adulto cuidador esteja com ele com todos os sentidos, receber o que emana dele para poder contêlo, acolhê-lo, transformá-lo. É necessário que ocorra uma regressão do adulto para suas experiências primárias para que ele seja capaz de identificar-se com o bebê.

Porém essa regressão pode não ser fácil para alguns adultos. Reviver essas experiências primárias pode ter um caráter quase inacessível para algumas pessoas que viveram infâncias extremamente traumáticas. $O$ adulto que hoje tem dificuldades de estabelecer contato com a criança de uma forma mais lúdica e afetiva - que tem com o bebê um contato mais voltado para satisfazer suas necessidades biológicas básicas de um modo mais "mecânico" - pode ser um adulto que experienciou essa relação do cuidado consigo no início de sua vida de uma forma mais enrijecida. Como podemos falar sobre ter cuidado com o outro para alguém que talvez não tenha sido cuidado de forma "saudável"?

Luís Claudio Figueiredo (2007) aponta para as diversas faces do cuidar como essenciais para o desenvolvimento humano. Ele dialoga sobre a importância de um equilíbrio dinâmico entre essas fontes de presença do cuidador e de como elas atuam em função das necessidades narcísicas do cuidador e em prejuízo dos seus objetos.

O modo como o outro se apresenta como agente de cuidados é determinante sobre a relação que o bebê vai ter com o mundo. O autor classifica dois tipos de presença deste agente em relação a criança: a presença implicada e a presença em reserva.

A presença implicada se trata de alguém que está ali para a criança de forma ativa e atuante - um objeto que desempenha as funções de acolher, hospedar, agasalhar, alimentar. Figueiredo se utiliza do conceito winnicottiano de holding 
para explicar essa ideia de sustentação, necessária para o bebê nessa etapa primordial de acolhimento e presença ativa necessária.

Além de facilitar as necessidades básicas da criança o adulto precisa atuar como um reconhecimento da existência do outro, em uma função de espelhamento. Em outras palavras, é necessário que exista alguém que afirme para o bebê que ele exista, através do olhar, do toque e do cuidado.

Muitas vezes cuidar é, basicamente, ser capaz de prestar atenção e reconhecer o objeto dos cuidados no que ele tem de próprio e singular, dando disso testemunho e, se possível, levando de volta ao sujeito sua própria imagem (Figueiredo, 2007, p.18).

Esse reflexo de si que se desenvolve através do reconhecimento da atividade do cuidador, acaba sendo o pilar formador da autoimagem e autoestima do objeto cuidado. Apesar de silencioso, é um cuidar que se resume em estar atento e responder na medida, quando e se for pertinente. Essa figura de alteridade proposta por Figueiredo conversa de todas as formas com a função de espelho proposta por Winnicott, já descrita anteriormente, como etapa fundamental para o desenvolvimento de um indivíduo saudável.

É necessário que haja um investimento narcísico no bebê que atinja uma dose tal que o bebê possa ainda preservar um pouco de suas singularidades. O encontro entre o bebê e o outro é traumático de modo que tem sempre algo ali que o escapa, que é de si, da própria sexualidade. Confrontar o enigma do adulto, do que lhe é diferente lhe desperta a vontade de perguntar, de perceber que lhe falta algo. $\mathrm{O}$ bebê vem-a-ser a medida da interpelação do adulto.

A presença implicada em excesso pode gerar diversos modos de aprisionamento psíquico, imobilidade e incapacitação. O indivíduo que tem um adulto que lhe faz tudo, não precisa se desenvolver para fazer nada, nem vir-a-ser aquilo que é si mesmo. Ao invés de desenvolver um ego integrado e criativo, se desenvolve um falso self onde a criança precisa ser aquilo que querem que ela seja. Rodeado pelos desejos narcísicos dos adultos cuidadores, o bebê se desenvolve com um sentimento de impotência demasiado e uma autocrítica arrasadora.

Com o fim de não ser invadido e dominado por desejos de outros, se destaca aqui uma importante figura de cuidado que é a presença em reserva. Nessa posição o cuidador exerce uma renúncia de sua própria onipotência permitindo que o objeto 
seja o próprio cuidador de si e até mesmo de exercer por ele mesmo a função de cuidador do outro.

Apenas quem introjetou criativamente as funções cuidadoras e as exerce com a mesma criatividade pode transmiti-las de forma criativa e eficaz e ajudar na constituição de sujeitos responsáveis (Figueiredo, 2007, p 24).

É essencial que o objeto dos cuidados tenha seu espaço próprio, desobstruído da presença do outro, onde ele possa viver e criar espontaneamente. É nesse espaço, que poderá explorar sua capacidade de sonhar, brincar, pensar e criar mundos.

Cada adulto cuidador tem sua própria história infantil, marcado por presenças e ausências. Adultos que não tiveram em sua própria trajetória de vida essa função do cuidado internalizada podem passar por situações muito difíceis quando se colocam nesse lugar de se tornar a figura de cuidador. Porém, se colocar nesse lugar também pode ser mais uma tentativa de integração - mesmo que tardia.

É muito comum observar na clínica com adultos - com filhos ou não - como a questão do cuidado é um ponto sensível na vida de cada indivíduo. Trazer à tona a infância, as relações com os agentes cuidadores são sempre alvo de muitas sessões de psicoterapia - melhor dizendo, são a base de todo o processo terapêutico. A pergunta: “com quem você brincava quando era pequena(o)?” é sempre um grande disparador de reflexões.

Relembrar a infância pode trazer à tona muitos re-sentimentos. Perceber a si mesmo em uma infância solitária ou até mesmo cercada de muitos excessos é um passo muito importante para a percepção de si no processo analítico. Junto com o analisando podemos buscar construir um fio condutor entre o que foi vivido na infância e o que se apresenta hoje, como o infantil dentro de si.

A cena recriada agora tem outros agentes. Não se trata mais daquela pessoa quando estava no início da vida sendo criada por um ambiente invasivo, que não lhe permitia ter espaços vazios que pudesse criar. Agora, é um adulto formado por muitas outras situações além dessa e é no espaço terapêutico que podemos trazer essas cenas iniciais para reelaborar com toda essa nova roupagem.

Não podemos deixar de ressaltar que a experiência da maternidade e da paternidade seja talvez o maior marco de mudança de posição de alguém - deixando 
de ser o objeto de cuidado para ser também o agente cuidador. Como podemos resgatar o brincar infantil do adulto na clínica com famílias?

A criança surge no contexto familiar como criadora de uma nova história, podendo inclusive, re-encenar algo que não pôde ser vivido antes, na história de seus pais. O dispositivo clínico se configura assim como um auxiliar no intuito de instaurar a possibilidade de brincar dentro dessa família. Desse modo, a criança traz consigo, nessa nova história, a possibilidade de reconstrução do brincar no adulto, que pode viver essa regressão sendo acolhida pelo dispositivo clínico. Suas histórias familiares iniciais são revividas nessa nova experiência de maternidade/paternidade. Quem eram quando eram crianças e quem ainda se mantiveram sendo a partir dessa experiência inicial quando convocadas nesse novo cenário de reconstrução do brincar adulto.

A “contribuição" que os pais podem dar à família que estão construindo depende em grande medida do seu relacionamento geral com o círculo mais amplo que os envolve, ou seja, seu contexto social imediato. Pode-se usar aqui a imagem de círculos concêntricos cada vez mais largos: cada grupo social depende, para ser o que é, de seu relacionamento com um grupo social mais vasto. (Winnicott, 1965, p.61)

Em uma família como a do caso de Antônia, apresentado anteriormente, marcada por uma mãe com questões psíquicas graves, tem como círculo mais vasto uma família que duvida de sua capacidade de ser mãe, além da veracidade de sua palavra. Ao duvidar da gravidez inicial, duvidam de quem ela pode ser nessa maternidade, desestruturando, desde o início, uma possível relação entre as duas.

Sob a égide de uma incapacidade de maternar, a mãe não consegue criar a estrutura necessária para o desenvolvimento saudável da filha. Assombrada por essas figuras parentais, sozinha, ela não consegue reescrever essa história. Winnicott aponta que os relacionamentos agradáveis tanto para a pessoa quanto para a sociedade representam um dos pontos culminantes para a saúde mental. A falta de validade em ser quem é aparece como uma barreira para essa satisfação e crescimento, acentuando essa distância entre a mãe e seu objeto de desejo/satisfação - a filha.

Porém, buscar um tratamento terapêutico aponta para uma família que tem o desejo de se estruturar, de se integrar. Perceber essa dinâmica destrutiva, evidenciada pelas crianças, proporcionam às famílias uma nova tentativa de se 
configurar, de reescrever suas histórias. É preciso trazer para o setting as angústias, medos e desejos, tanto dos adultos cuidadores quanto da criança, pela via do brincar. Construir com o adulto essa possibilidade é criar novos recursos para permitir sua reestruturação.

O bebê, a criança nova e a criança mais velha nos lisonjeiam por esperarem de nós uma certa confiabilidade e disponibilidade, ao que respondemos talvez, em parte, devido a nossa capacidade de identificarmo-nos com os filhos. Essa capacidade, por sua vez, depende de termos desenvolvido nossa própria personalidade de modo satisfatório quando tínhamos a mesma idade que ora têm os filhos. Desse modo, nossas próprias capacidades são descobertas e desenvolvidas pelo que os nossos filhos esperam de nós (Winnicott, 1965, p.71, grifo do autor).

Para desenvolver sua integração, cada indivíduo parte de um estado de nãointegração. Em condições favoráveis normais, o bebê é capaz de manifestar uma tendência inata à integração. Em casos de famílias mais desestruturadas, de adultos que não conseguem estabelecer esse espaço seguro e saudável, o bebê possui uma dificuldade de se integrar, como no caso apresentado. A tentativa de integração da criança, nesse molde, surge como uma tentativa de integração também de toda estrutura familiar, com todos os seus integrantes.

A partir de adultos que não conseguiram desenvolver essa personalidade, como coloca Winnicott no trecho acima, a chegada dessa criança se apresenta como uma nova esperança de desenvolvimento individual de cada integrante dessa família. É uma chegada turbulenta e repleta de dificuldades, porém a busca por um acompanhamento psicológico se torna um fator determinante para esse novo movimento familiar.

Realizar esse trabalho junto das famílias e adultos cuidadores é poder se inserir nessa dinâmica familiar, escutar suas dificuldades e experiências e prover um ambiente seguro para essas importantes trocas, tornando-as possíveis. Para além de observar o conteúdo da brincadeira da criança, é preciso retomar as experiências sensoriais primevas, que garantam a sensação de continuidade. Prever o que vai acontecer, nomear as situações, objetos e sentimentos. Falar sobre si e emprestar nossa própria disponibilidade de criar um ambiente provisional possível para que a criança possa ser criativa, auxiliando-a na construção de seu eu integral.

E, além de um olhar para a criança, é preciso um olhar atento ao adulto, para suas demandas e possibilidades. Estar junto, facilitando alguns processos, co- 
construindo novas possibilidades de relações e criando brechas para que o self de cada um possa advir. Dessa forma, é possível co-criar com as famílias uma nova história.

Para se construir, para nascer e para crescer, mesmo os bebês têm necessidade de uma história - e não somente uma história biológica ou genética, mas também de uma história relacional. (...) A maneira pela qual a criança resiste a certos mandatos e projeções define, na verdade, uma parte de sua resiliência e assim se evidencia, a partir de então, a criança historiadora da história que ela mesma contribui a escrever (Golse, 2002, p.73).

Segundo Golse, o objetivo dos diferentes enquadres terapêuticos é o de recolocar os pais em posição criativa e dinâmica em relação a criança, tratando assim de uma transmissão da capacidade de transmitir. Os terapeutas não transmitem seus próprios conteúdos psíquicos mas fornecem as apropriações identificatórias relacionais necessárias para os pais e para a criança a partir das suas modalidades de continência e de transformação psíquica.

O terapeuta aparece assim como um objeto terceiro que deve ser 'suficientemente maleável' (M. Milner) e narrativo, a fim de co-escrever com as tríades uma história que talvez não seja a dos acontecimentos reais, mas sim uma história que possa dar toda a sua coerência existencial ao sofrimento, a fim de recolocar as dificuldades da criança em perspectiva com sua biografia e com aquela de seu grupo familiar, social e cultural (GOLSE, 2003, p.74).

A construção de uma narrativa para a história da criança traz consigo uma possibilidade de reescrever a história dos adultos, sob uma nova ótica, em cima de uma nova experiência de infância. Brincar com a criança é acessar sua própria história e reescrevê-la a partir de novos recursos adquiridos - é se relacionar consigo mesmo e com o outro.

\section{2.}

\section{A parte bebê do adulto}

Albert Ciccone (2008) propõe que existe uma diferença entre o infantil e o arcaico, onde o arcaico seria algo que diz respeito à origem, ao primário, que deixa traços no modo do indivíduo se relacionar com o mundo e seus mecanismos de defesa. O infantil seria algo da experiência subjetiva, que vai além. É uma cena que 
ainda está ativa, presente, que coexiste com partes da personalidade mais maduras, que passou por um processo de adaptação e integração da realidade.

O sofrimento mental mais intolerável é sempre aquele experimentado pela parte infantil do eu, a criança em si mesmo, ou até o bebê em si. O sofrimento do adulto nunca é o mais desorganizador; mesmo que seja violento doloroso, afeta partes maduras que pode usar recursos adaptativos. O sofrimento infantil é o mais escandaloso, o mais desorganizador, o mais insuportável (Ciccone, 2008, p.133, tradução livre)

Considerando as experiências iniciais como estruturantes do nosso psiquismo, algo que aconteceu no passado deixa marcas em toda a história de vida do sujeito. Porém, não se pode olhar esse marco como algo que aconteceu e ficou no passado. Os efeitos psíquicos desse sofrimento seguem, na história presente do adulto, nas experiências atuais. É preciso supor essas histórias infantis como algo que se reatualiza nessas vivências, como em uma parte bebê do adulto.

Esse é um fator importante ao se pensar sobre a prática clínica. Enquanto psicólogos ou psicanalistas, estamos tratando ali de algo que se passa no presente e não apenas algo que se deu em um passado histórico. Existem traços que compõem quem aquele sujeito é naquele momento que foram formados a partir dessa história infantil.

O autor sugere que "o trabalho de assistência psíquica não é um trabalho arqueológico; a atenção deve ser dada ao aqui e agora, no lugar onde a intimidade é criada, no lugar em que o sujeito adquire responsabilidade por sua vida psíquica" (Ciccone, 2008, p.134, tradução livre). Esta percepção denota um caráter atual para o sofrimento, no modo como ele opera no aqui-e-agora, até mesmo na transferência clínica.

A experiência da parentalidade surge como algo que remete a criança edipiana em si, fazendo-os se reconectar com seus próprios pais e sua experiência de ser filho. Suas experiências infantis e arcaicas geram efeitos na relação com os filhos, como uma certa rivalidade narcísica.

Os pais também vão enfrentar na rivalidade narcísica suas experiências mais arcaicas. O bebê é um rival narcisista. Ele representa o bebê rival de infância bebê real ou imaginário - que monopolizou a atenção dos pais, que fez o sujeito perder o amor exclusivo do qual ele se beneficiava ou que é responsável pelo fato de o sujeito nunca ter tido amor suficiente (Ciccone, 2008, p.136, tradução livre) 
Desse modo, essas experiências infantis e arcaicas também tecem os vínculos da relação pais-bebê, gerando afetos de ódio, ciúmes, inveja, rejeição e não apenas na relação com o bebê mas pode se repetir conforme a criança se torna adolescente e, posteriormente, na sua fase adulta.

É importante ressaltar que a observação de bebê e a psicoterapia com as crianças são fatores muito relevantes para estudar e entender essa parte infantil do adulto. Construir uma escuta clínica sensível para essas questões é fundamental para o tratamento não só das famílias, como dos adultos sem filhos em geral.

Pensar o brincar na clínica, e trazê-lo efetivamente para o setting terapêutico, torna-se uma ferramenta essencial para entender o modo do funcionamento psíquico. É uma busca pela história do brincar no passado que se reatualiza com a possibilidade ou impossibilidade de brincar no presente.

A concepção de que o psiquismo se constrói a partir das trocas afetivas, verbais e não-verbais, entre o bebê e seus adultos primordiais, nos mostra que essa relação de cuidado vai servir de fio condutor na constituição do psiquismo de um sujeito.

Ciccone (2008), propõe, assim como Figueiredo (2007), que é necessário um olhar mais atento para esse cuidado inicial. Primeiramente, pontua o cuidado como encontro, diante da experiência fundamental de fazer contato com o outro e com o mundo, sendo inicialmente acompanhado por um adulto primordial. Nesse ponto é ressaltada a dimensão intersubjetiva da experiência em geral, e no nível de disponibilidade que o adulto deve se submeter.

Destacamos, por exemplo, o papel, a função essencial das experiências de compartilhamento emocional, compartilhamento de afeto, afinação, regulação emocional mútua, criação comum de experiências subjetivas. Tais experiências que se qualificam não apenas para o desenvolvimento psíquico do bebê, mas para o desenvolvimento de todos, e particular de todos, confrontados com tormentos, dor psíquica, desconforto, o que não só pode ser superado por um processo de crescimento mental, um processo que envolve um objeto, outro, o funcionamento psíquico de um outro, o espaço mental do outro (Ciccone, 2008, p.141, tradução livre)

Como já apresentado anteriormente, o compartilhamento de prazer no encontro é estruturante para a dimensão subjetiva psíquica. $\mathrm{O}$ bebê procura uma experiência comum, compartilhada, para atribuir sentido às situações. Sinais muito enigmáticos geram uma confusão nesse processo de atribuição de sentido. 
Como por exemplo, nos casos de mães depressivas que possuem uma grande dificuldade de modular suas expressões faciais diante das diferentes emoções expressadas pelo bebê. É preciso que o adulto compartilhe os afetos de vitalidade diante da criança para que ela possa identificar os momentos em que pode estar relaxada e os momentos de perigo/alerta.

A falha nessa troca, um descompasso rítmico, gera na criança uma certa desconfiança e falta de previsibilidade - que podem ser desestruturantes, se constantes. O processo de percepção de si passa pela percepção do outro, que é utilizado como sua referência. Quanto mais constantes e nítidos forem essas expressões, mais possível é para o bebê se reconhecer e se integrar.

Esse mecanismo de olhar para o outro como referência para a auto percepção, o que Ciccone (2008) chama de olhar referencial, é comum não apenas nas crianças, mas também nos adultos. Mesmo o adulto recorre ao olhar de outra pessoa que serve como referência em situações de dúvidas, ou conflitos emocionais.

$\mathrm{Na}$ clínica podemos observar esse movimento frequentemente quando atendemos crianças acompanhadas de seus pais que, ao se depararem com brincadeiras "indevidas" ou situações constrangedoras, nos lançam um olhar que visa encontrar alguma resposta para aquela situação. Isso acontece em diversas situações cotidianas, como uma criança de dez anos que começa a engatinhar no consultório e a mãe que a acompanha demonstra um nítido incomodo na situação, ou em alguma situação que tenha um caráter mais sexualizado e o cuidador que acompanha a criança imediatamente lança um olhar para a terapeuta presente. Esse olhar referenciado aponta para a construção desse vínculo afetivo de confiança.

Outro ponto fundamental do lugar de cuidado descrito por Ciccone (2008) é a integração da unidade. Como já apresentado aqui anteriormente, a partir de uma perspectiva de Winnicott, essa conquista da unidade psíquica é um trabalho realizado conjuntamente com esse cuidador primordial, que auxilia o bebê a conter e dar um contorno ao seu corpo, a partir do holding e do handling.

A mãe, assim, realiza um trabalho de direção, de integração de unidades. Ela ajuda o bebê a amarrar o ódio ao amor, a transformar a violência interna em comunicação lúdica. E ela pode fazer isso porque ela não é destruída pelo movimento destrutivo. (Ciccone, 2008, p.144, tradução livre). 
Nos casos em que a mãe é realmente destruída, algo pode ser colocado ali apontando para essa destruição. Uma fala, um movimento ou um gesto. Se colocar nessa posição de construir, junto do bebê, os limites de si e do seu próprio psiquismo, do contorno do seu corpo e dar respostas para suas ações, é um passo fundamental na busca por essa integração.

A ideia de reanimação psíquica supõe partir do único ponto de investimento residual para, gradualmente, ampliar o campo de investimento. Esse trabalho seria voltado para trazer de volta uma subjetividade apagada, que ocorre especialmente após experiências traumáticas quando a capacidade de investimento se encontra reduzida ao mínimo.

Nesses casos, o cuidador primordial tem essa tarefa, de resgatar o bebê desse estado de congelamento do desejo, do eu petrificado, onde seu investimento no bebê o auxilia a ampliar seu mundo retraído. Na observação dessas situações é possível desenvolver importantes ferramentas para trabalho no setting clínico - sobre como é importante, por exemplo, a nós psicólogos de fortalecer essa ponte existente entre adulto cuidador e bebê, respeitando o tempo possível de cada criança.

E por último, o autor apresenta a consolação como modelo de assistência psíquica, que se refere a consolar, acolher, dar apoio, ao sujeito com alguma angústia ou sofrimento. Essas seriam exatamente as experiências de compartilhamento de afetos e regulação emocional que só podem ocorrer em um meio seguro e confiável.

Esses mecanismos de cuidado foram retirados de uma experiência de Ciccone na observação de bebês e são apresentados aqui como sendo fatores fundamentais para a clínica, não apenas com crianças e famílias mas para a clínica com adultos em geral. Existe em todo adulto essa parte infantil que, mesmo no momento presente, ainda precisa de cuidado e de trocas seguras e confiáveis.

Com isso, torna-se necessário perceber que para fazer um trabalho terapêutico com crianças é imprescindível a presença de seus pais na clínica. Em muitos casos, é importante trabalhar primordialmente com essas famílias, esses adultos, que possuem tantos sofrimentos e angústias guardados para si. O estímulo, através do brincar, nessa experiência de compartilhamento de afetos dentro da clínica, do setting, pode reverberar no cotidiano de cada família. 


\section{3 \\ O brincar na família: co-construindo uma nova história}

A parentalidade é um processo que se constrói no encontro intersubjetivo dos pais com a criança. É a partir desse encontro que se dá a co-construção de uma nova história. Tanto os pais quanto os filhos, são agentes ativos nesse processo existe uma mutualidade nas trocas entre pais e bebês que permite a apropriação do lugar dos pais pelos adultos e a construção da subjetividade dos filhos.

O nascimento de um filho implica uma dupla dimensão: para que um bebê sobreviva física e psiquicamente, é necessário inscrevê-lo em uma história familiar e transgeracional. No entanto, a dimensão ascendente da transmissão (filhos-pais) é igualmente fundamental, pois só o reconhecimento do filho em sua diferença permite aos pais construir uma relação com a marca do novo e da criatividade, indo além de uma repetição do passado e permitindo que o bebê se aproprie das marcas e inscrições de sua história relacional inicial. (Zornig, 2010)

Os filhos, dessa forma, não são reféns das histórias parentais, ao contrário, são personagens ativos de sua própria história. Existem marcas que os pais carregam em si de sua própria história, mas que podem, a partir da chegada do filho, também se recolocar nesse novo cenário.

Lebovici (1987) propõe que os bebês carregam a marca da problemática parental, entendendo que seu processo de filiação se inicia muito antes do nascimento do bebê, até mesmo da sua concepção, perpassando sobre a própria representação dos seus pais sobre o ser pai e ser mãe. Desde pequenos, os pais já constroem um imaginário do que seriam os filhos, e desde então já existe algo da pré-história desse sujeito que se instaura.

Porém, é necessário apontar também que esse processo de parentalidade é modificado pela presença real do bebê. Seu psiquismo se forma e transforma a partir de todos estes encontros e trocas afetivas que narramos anteriormente, entre o infante e seus adultos primordiais.

Essas questões apontam que, como dizia Lebovici, o bebê faz seus pais, ele constrói e parentaliza os pais, ao mesmo tempo que ele mesmo se constrói. Se ele é dependente da mãe, ele não é um reservatório passivo dos cuidados maternos. Trata-se da interdependência entre os processos de maturação da criança e da vida imaginária da mãe, que será vinculada nos cuidados que ela oferece a sua criança (Solis-Ponton,2004, apud Dadoorian, 2018, p.116) 
Existe algo de constitutivo na transmissão transgeracional, isto é, que se herda das histórias das avós e dos pais, no que tange aos conflitos psíquicos e narcísicos inclusive. Diana Dadoorian (2018) aponta para essa relação entre as histórias familiares e a transmissão psíquica partindo do princípio que se entende a subjetividade como uma construção também atravessada pela narratividade.

Essa transmissão é essencial para a construção da subjetividade da criança, para suas identificações e construção de personalidade. Nas palavras da autora: "Quanto maior for a consciência dos pais sobre essa questão, maiores serão as chances que eles terão de dar ao que é transmitido a seus filhos o valor de nutriente de que eles necessitam” (2018, p.117). Ou seja, é importante narrar para a criança sobre a história de sua família, pois ela também diz de sua própria história.

Os conflitos inconscientes, não elaborados na geração anterior, transmitidos para as crianças aparecem na forma de um mandato, e a criança pode ser utilizada na reparação desses conflitos infantis dos pais. Ela surge como uma descontinuidade psíquica, um vazio na trama das representações daquela criança.

Por isso, o trabalho de resgate dessa infância esquecida dos pais também surge como uma importante ferramenta de trabalho clínico. Compreender o que se passa com essas famílias, o sentido do sintoma, o que existe de passado no presente, e suas formas de reatualização são questões essenciais para serem trabalhadas com as famílias.

Isto é, mais do que vasculhar o que ocorreu no passado dos pais, é preciso ouvir o que se presentifica desse passado na história narrada por eles, buscando entender o que se coloca na relação com a criança e na relação da criança com o mundo. Se permitir brincar, assim, é uma via de contato as suas próprias angústias primitivas e é preciso um trabalho de acolhimento sensível e contorno psíquico também voltado para os adultos nesse espaço clínico.

\section{4}

\section{A família dentro do consultório psicoterapêutico}

Alguns ainda cometem o erro de pensar, por exemplo, que a psicanálise infantil seria mais simples, e menos nobre que a psicanálise adulta. A realidade é completamente o oposto. Experiência com crianças, até bebês, é instrutiva para todos os cuidadores da vida psíquica. Deveria ser 
obrigatório para todos. Ela de fato é em algumas escolas da psicanálise. (Ciccone, 2008, p.140, tradução livre)

Propor uma clínica com crianças e famílias, é propor um espaço em que possamos sentir, juntos, tudo aquilo que ali se apresenta. Através do brincar, dos jogos e brincadeiras, trazemos à cena questões psíquicas profundas sobre si mesmo e sobre a qualidade das relações. Intervir nesse primeiro tempo de vida de uma criança significa intervir em uma etapa na qual ela ainda está em processo de constituição psíquica, isto é, um momento fundamental para seu desenvolvimento psíquico.

Para isso, dois fatores são primordiais: a noção de corporeidade, isto é, de que o psiquismo é inaugurado no corpo, através das suas primeiras experiências sensório-motoras e da sua relação com o meio; e a importância de um objeto enquanto referencial psíquico, na dimensão da qualidade da presença afetiva para a construção da subjetividade (Zornig, 2010).

Construir uma clínica com crianças depende diretamente da forma como se relaciona com esses aspectos. Perceber a importância da integração corporal e poder ter um olhar sensível para essa construção além da função representativa do analista enquanto objeto primordial, na transferência.

A ideia de meio maleável, proposta por Marion Milner (1977), que tem uma ligação direta com ao conceito de transicionalidade e espaço transicional de Winnicott, é essencial para pensar nesse formato de clínica. É preciso ter um analista em cena que, como o objeto, apresente todas as características fundamentais da maleabilidade: indestrutibilidade, sensibilidade, transformabilidade, disponibilidade e a sua vitalidade (Roussillon, 1991).

Como o objeto primordial, o analista deve poder ser atingido e destruído, mas deve sobreviver a essa destruição. Esse processo faz com que ele se transforme, possibilitando que ele, enquanto objeto, represente a função representativa. Ele não pode ser alterado em sua natureza fundamental facilmente, mas deve fornecer uma certa sensibilidade a pequenos esforços - mas é fundamental que siga vivo.

Roussilon (1991) situa o enquadre psicanalítico como um determinado espaço-tempo que delimita um dentro e um fora propondo uma analogia com um quadro de pintura: 
Na pintura, o pintor utiliza meios através dos quais pode exteriorizar uma parte de sua realidade interior. A obra, produzida num estado psíquico de concentração, realiza a fusão de uma parte da realidade interior com uma parte da realidade exterior. Essa "fusão" dá origem a um símbolo que não é uma formação defensiva, mas resulta, ao contrário, de uma necessidade fundamental de organização e de coerência interior (Roussillon, 1991).

A transferência com a analista, nesses moldes, se torna palco para a ilusão de onipotência da criança, agindo então como esse objeto primordial que lhe garante a continuidade de existência e lhe permite co-construir um espaço seguro de conexão com o mundo.

A escuta clínica com crianças aponta para uma grande sensibilidade e disponibilidade tanto psíquica quanto corporal. É preciso estar junto, brincar junto, emprestar seu próprio corpo para essa troca. Pontuar limites em si, para possibilitar a criação de limites na criança. E para além de si, é preciso criar um ambiente estruturado pela confiabilidade e segurança, que permita a criança a acessar a experiência de continuidade de existência.

\subsection{1 \\ A ausência da família e a presença da criança - uma experiência de descompasso familiar}

A demanda de atendimento psicoterapêutico surge a partir de Joana, mãe de Sofia (9 anos), por queixas de ansiedade apresentadas em movimentos repetitivos com as mãos que lhe causavam pequenas fissuras, dada a quantidade de repetições. Nas entrevistas iniciais, sua mãe narrou sobre a chegada de Sofia à sua família, através de uma adoção realizada quando a menina tinha seis anos.

Joana narra a história de Sofia como uma criança que vivenciou um início de vida muito difícil. Sua mãe biológica se tratava de uma mulher dependente química que vivia com ela em condições de vulnerabilidade social fortíssimas até os seus 4/5 anos quando foi para um abrigo. Joana tem uma grande dificuldade de contar sobre essa história, se referindo a ela como algo do qual ela não gosta de se aprofundar e imaginar.

A menina chega no consultório pela primeira vez excessivamente animada. Demonstra estar sempre muito feliz e tem muitas dificuldades de afirmar que certas situações a deixam triste. Se refere a tudo que lhe é apresentado como algo que ama, 
e na primeira sessão produz uma série de desenhos junto da analista dizendo que a ama e distribui seus desenhos pelas paredes do consultório.

Sofia passa a sensação de possuir um discurso de reprodução de palavras esvaziadas afetivamente, que se guiam pelo que a outra pessoa teoricamente gostaria de ouvir dela. Em contraposição a isso, quando se frustra, se deita no chão e se debate, como um bebê, pedindo colo para a mãe e verbalizando a vontade de mamar.

A partir da sessão que a mãe passa a se retirar da sala, todas as "despedidas" são marcadas por uma sensação de perda acentuada, com uma fala sentida que desaparece no momento em que fecha a porta. Suas brincadeiras, nesse momento, são relacionadas a ser bebê, engatinhar, pedir colo. $\mathrm{O}$ ambiente de análise então passa a ser um espaço em que ela passa a regredir e a analista passa a ocupar esse lugar de cuidado, a partir de uma presença implicada extremamente necessária.

Repetidamente, Sofia invade o corpo do outro, sem parecer ter a dimensão de seu próprio corpo, tamanho e peso - ela é inclusive uma menina bem grande para a idade. Nas entrevistas seguintes com Joana, ela passa a relatar outras questões comportamentais da filha, como enurese e encoprese eventual, que, segundo ela, acontecem em momentos de muita ansiedade.

Ambos os pontos nos encaminham para uma reflexão sobre a construção inicial de limites do corpo, de contorno corporal e psíquico. Suas experiências iniciais de vida possivelmente não puderam lhe fornecer uma formação egóica estruturada, diante de uma situação de vulnerabilidade extrema, com abusos e violências constantes.

Podemos entender assim, a cena analítica como uma nova tentativa de constituição psíquica. Ela precisa inicialmente, reviver as experiências primárias, onde tivemos uma série de atendimentos onde ela se enrolava em panos, em posição fetal, seguindo para o colo da analista. Com fala de bebê e necessidade de carinho e amparo. Foi trabalhado ali, no espaço terapêutico, essa necessidade de recriar sensorialmente experiências primárias e paralelamente, construir espaço para que ela pudesse crescer.

Todo esse atendimento se deu por uma via corporal e afetiva, de troca sensório-afetiva. Foi preciso criar um espaço no corpo da analista que pudesse receber e acolher esse bebê que chegava. A disponibilidade para o 
compartilhamento de afetos e sentimentos é um fator essencial para a clínica com crianças - e o brincar é o elemento base desta troca.

É necessário, num primeiro momento, que o analista acolha a linguagem não verbal emitida por seu paciente, considerando-a como uma forma de comunicação fundamental de acesso à dimensão inconsciente. $\mathrm{O}$ olhar, o tom de voz, o ritmo, a expressão facial, o movimento corporal e toda a gama de impressões sensoriais comunicam o inconsciente do analisando e, portanto, ajudam-nos a entrar em contato com o que estava silenciado. (Fuchs e Zornig, 2013, p. 347)

Tratamos aqui essa linguagem como o próprio brincar em si, uma troca entre sujeitos, em um mesmo espaço e tempo. O que se encontra silenciado aqui é toda história de vida inicial de uma criança que fora obrigada a anular entendendo uma nova possibilidade de vivência com uma nova família. Dar lugar para essa cena inicial de vida, com todo o sofrimento que lhe cabe, foi fundamental para seu desenvolvimento. A relação de confiança estabelecida no setting analítico fora estruturante para toda essa possibilidade de nomear as experiências, trazê-las de volta e representá-las sob uma nova estrutura de vida.

Nas primeiras entrevistas foi apresentado por Joana a vontade de que ela tivesse um lugar para falar sobre todo o seu passado, da sua "outra família" pois fazer essa escuta, para ela, era insuportável. O trabalho a ser realizado ali com ela era de uma tentativa de construção dentro daquela "nova" família para a história de vida da Sofia.

Porém, durante todo o ano de atendimento com Sofia, foi estabelecida uma grande dificuldade em acessar seus pais. Apesar de serem, majoritariamente os responsáveis por levá-la a sessão de psicoterapia, marcar uma entrevista com eles era extremamente penoso. Essa falta de amarração da história da criança com a história dos seus familiares, bem simbólica de toda história do caso foi providencial para a relação transferencial entre a analista e os pais.

Foram poucas as entrevistas realizadas com eles. Em uma delas, desta vez na presença de ambos os pais, foram levadas duras críticas ao fato da menina se apresentar muito queixosa, sendo utilizado como exemplo sua maior seletividade nas refeições, o que não acontecia anteriormente. Segundo a família, quando indagada o motivo da recusa Sofia lhes confidenciou que nunca gostara daquela comida, e que antes os estava enganando, mas que agora poderia lhes contar a verdade. Pela primeira vez, em quatro anos na nova casa, ela pode dizer de si, do 
que gostava ou não, sem medo de retaliação - algo que foi visto pelos pais como um novo "problema" criado pela análise.

A distância entre a família e o processo terapêutico denunciava a distância entre eles e Sofia. A impossibilidade de costura entre a criança e seu ambiente familiar surgiu como o maior fator disruptivo desse atendimento. As tentativas de trazer a família para brincar junto eram muito pouco acolhidas - quando aceitavam a proposta, apresentavam constantemente uma tentativa de encenar algo que se gostaria que fosse dito, enquanto jogava uma bolinha. Era difícil acessar algo da experiência em si.

Paralelamente, o atendimento com Sofia foi ganhando contorno. Através de leituras de histórias, construções de cabanas e jogos de bola, foi possível construir uma relação afetiva já mais madura, permeada por desejos e vontades. Foram produzidos no consultório diversos desenhos que contavam histórias, a linha do tempo de sua vida. Foi trazido para o enquadre terapêutico suas histórias de criança, suas tristezas, seu desejo de narrar e elaborar suas experiências de vida.

Mais do que uma reagir defensivamente a um ambiente que a oprime, Sofia foi se munindo de ferramentas possíveis para poder agir espontaneamente; dotada de diversos sentimentos e quereres. A possibilidade da analista de sustentar, conter e sobreviver a tudo o que ela trazia para o setting foi fundamental para esse processo. $\mathrm{O}$ encontro ali era permeado por estratégias de cuidado.

Porém, conforme a aproximação e o vínculo transferencial com Sofia se intensificava, mais distante a família se colocava, culminando no fim do tratamento. A ausência da família no setting aponta para esse distanciamento entre as experiências vividas por Sofia, a ruptura entre suas experiências iniciais de vida, com sua família biológica, e sua chegada na nova família - em um grande descompasso familiar. Deste modo, as constantes tentativas de trazê-los para o consultório, para a brincadeira e para a cena eram recusadas.

Para se fazer clínica com crianças e famílias é preciso que todos os agentes se responsabilizem enquanto presença ativa nesse processo. É preciso reformular a dinâmica de famílias adoecidas, recriando e co-construindo um espaço possível para todas as narrativas. Encontrar um novo ritmo familiar. Realizar esse trabalho com a presença dos adultos no ambiente psicoterapêutico é fundamental.

O caso apresentado traz a história de uma família na qual adultos e crianças são muito distantes subjetivamente. Muitos outros casos poderiam ser utilizados 
como exemplo, de famílias que, em contraposição, são extremamente presentes mães e pais que tem muita dificuldade de deixar as crianças no consultório e se retirar do espaço. Em ambos os casos, o que está sendo retratado são os excessos no investimento familiar na relação com a criança, onde não foi possível realizar uma alternância saudável entre presença/ausência. 


\section{5 \\ Considerações Finais}

Essa pesquisa se inspirou na observação clínica de crianças e famílias frequentadoras da ONG Casa da Árvore ao longo dos últimos três anos. A percepção da dificuldade das famílias de se disponibilizarem a estar com as crianças na brincadeira e na troca nos forneceram elementos para desconfiarmos de uma tentativa de distanciamento desse processo de construção psíquica por reverberarem em suas próprias dores e inquietações.

Para trabalhar com a criança na clínica é preciso primordialmente perceber que o seu processo de constituição psíquica se inicia desde suas primeiras trocas afetivas. A mãe, ou adulto primordial, funciona como um primeiro objeto relacional, o qual, a partir da intersubjetividade, inicia um processo de construção egóica. O brincar se faz presente desde os primeiros momentos, pela troca de olhares, o toque, a identificação - são aspectos que se configuram como a base do nosso psiquismo.

A noção de sensorialidade aqui se faz fundamental de ser apresentada, pois é a partir dela que o eu se constitui. Como aponta Konichekis (2018) é desde a vida intra-uterina que o bebê começa a ter essas primeiras sensações e trocas com a mãe, possivelmente já criando um certo "estoque" de memórias corporais. Esse estoque vai formando gradativamente o conjunto de experiências que dão contorno ao ser.

As primeiras experiências de um bebê são todas fragmentadas, e nesse início, é providencial que exista alguém que lhe dê uma sustentação, um contorno para essas experiências. Como sugere Hélia Borges (2011), o ego seria algo que resultaria de uma soma de começos, uma soma de experiências sensoriais, um campo de forças múltiplo que se coloca como um corpo vivo, móvel.

A confiança assim se apresentaria como base dessa construção a partir da possibilidade de criação de um ambiente seguro no qual existe algo que o sustenta, que não se destruirá. Um outro continente, que o ampara e acolhe. Um outro previsível. É preciso que o ambiente, no seu caráter facilitador, garanta essa indestrutibilidade que permita a espontaneidade da criança. A sensação da criança 
de confiança e a garantia da previsibilidade incita uma experiência de continuidade do ser.

A ideia apresentada por Roussillon (2006) de que para que essas trocas afetivas se deem seja necessário que haja um compartilhamento de afetos, nos parece fundamental para entender essa relação. $\mathrm{O}$ autor aponta que é necessário que exista um prazer nesse vetor do encontro, para que o bebê possa vivenciar uma experiência de intersubjetividade, onde o objeto se propõe, mas não cole nele.

Entendendo que para que o processo de subjetivação possa acontecer é necessário uma alternância entre a presença e ausência do adulto cuidador, essa ausência só pode se dar em um contexto que soe para a criança como algo confiável, e não disruptivo. É necessário então nessa alternância um movimento gradual e rítmico, de modo que propicie uma descontinuidade que permita que o bebê possa criar no ambiente algo que lhe falta.

Roussillon (2006) propõe que a função dos objetos primordiais é fortalecer as experiências primeiras na medida que o objeto ofereça possibilidades. A abertura para o mundo se dá na confiança da continuidade de existência, do interesse que o outro provoca. Desse modo, podemos entender que só é possível que esse adulto fortaleça o outro a criar outras possibilidades de mundo, se o próprio adulto vive essa experiência de segurança e confiança em si, na sua própria história.

Sendo assim, a função do setting terapêutico seria a de auxiliar a família a encontrar esse prazer no encontro, perceber onde se localizam os bloqueios e coconstruir com a família uma possibilidade de reparação de uma história. Desse modo, o analista funciona como "tradutor" ou "ponte" entre o mundo infantil do adulto, as experiências sensoriais e representacionais, utilizando de uma escuta sensível e um corpo presente, maleável.

Para Winnicott (1965), o brincar é por si só uma ferramenta terapêutica e cabe ao analista trazer o paciente de um estado em que não é capaz de brincar, para um estado em que o é (1975, p. 59). A utilização do espaço potencial construído no ambiente clínico permite o estabelecimento de um novo ritmo possível para a interação dos agentes ali presentes, levando em consideração a narrativa de cada um através do brincar.

Desse modo, fazer clínica com crianças é estar ciente de que essa história é marcada pela história dos seus pais, através de uma transmissão psíquica transgeracional. No cuidado com as crianças existe muito de si, da sua própria 
experiência de ser cuidado. Existe algo do infantil do adulto que se reatualiza na relação com a criança. Trabalhar isso na clínica se mostra fundamental.

No olhar para a criança, é preciso um olhar atento ao adulto, para suas demandas e possibilidades. Estar junto, facilitando alguns processos, coconstruindo novas possibilidades de relações e criando brechas para que o self de cada um possa advir. Dessa forma, pode ser possível co-criar com as famílias uma nova história.

Refletir sobre o cuidado dos adultos é refletir sobre a possibilidade que eles têm de cuidar das crianças. Investigar essa história é uma forma de auxiliar a criança e o adulto na apropriação da própria história, de construção de sua própria narrativa, podendo assim elaborar as falhas e criar novas possibilidades de ser.

Nosso estudo procurou se debruçar na possibilidade de presença dos adultos cuidadores no espaço clínico, criando ali um espaço de experiência para toda a família. O brincar com os adultos é brincar com o infantil deles, que não se permitiu brincar em um outro momento de vida. É afirmar esse espaço seguro para todos, possibilitando essa co-construção também fora do espaço clínico.

É desafiador criar essa relação com os adultos, e por vezes, ainda mais do que com as crianças. Também é extremamente delicado o limite entre o que tange aos pais na análise das crianças, e o que se torna uma análise pessoal do adulto. Mas esse embolado aparece na clínica exatamente para que possamos atuar no auxílio do desembolar. O espaço de narração criado a partir de uma experiência de prazer compartilhado permite a família criar uma outra possibilidade de história - onde nós, analistas, atuamos para garantir a liberdade dessa co-construção. É preciso olhar atentamente para perceber de onde surgem os bloqueios, as paralisações, reconduzindo criança e adulto para a conquista da espontaneidade.

Não existem regras ou fórmulas. O trabalho clínico é baseado no caso-acaso. É impossível obter uma resposta generalista que abarque todas as impossibilidades do brincar nas famílias. O que é certo é que para o desenvolvimento das crianças, é preciso da presença dos adultos, do cuidado, da atenção e do carinho - de sua disponibilidade afetiva. E o brincar surge a partir dessa disponibilidade. Em famílias onde o brincar não é possível, talvez nosso olhar clínico precise estar em construir essa disponibilidade junto com os agentes de cuidados. Encontrar brechas, espaços, que possibilitem a criação desse espaço potencial - confiável e seguro. 
Com isso, não pretendemos encerrar aqui as discussões acerca do brincar e do não-brincar familiar e como isso repercute no desenvolvimento das crianças. Existem ainda diversos outros pontos importantes que podem engrandecer esse debate, como por exemplo a discussão sobre a terceirização do cuidado ou sobre como trabalhamos a ludicidade na infância em uma era tão tecnologizada onde as crianças estão, cada vez mais novas, sendo mais rodeadas por telas? Como criar tempo de qualidade para estar junto dos filhos ao mesmo tempo que se tem altíssimas exigências de produção de trabalho?

São muitos os caminhos que o estudo sobre o brincar pode levar. Dentro ou fora da clínica, no campo da psicologia, psicanálise, pedagogia... o brincar está presente em todos nós, adultos ou crianças, e é preciso um olhar atento para isso. Falar sobre o brincar, é falar sobre saúde - sobre cuidado. O brincar é atemporal e extremamente específico. É sobre encontros e disponibilidades. Brincar é poder criar. 
Referências bibliográficas

ARAGÃO, R. Entre a mãe e o bebê: continuidade, descontinuidade e ritmo. In: Continuidade e descontinuidade no processo de subjetivação do bebê. São Paulo: Escuta, 2018. p. 29-41.

BARBOSA, C; SILVA, M. N. Um lugar para brincar e conversar. In: A casa da árvore: uma experiência inovadora na atenção à infância. Rio de Janeiro: Garamond, 2008. p. 95-118.

BEZERRA, B. J. Os desafios de um experimento. In: A casa da árvore: uma experiência inovadora na atenção à infância. Rio de Janeiro: Garamond, 2008. p. $15-29$.

BORGES, H. M. O. C. Entre a palavra e o movimento. In: Cadernos de Psicanálise - CPRJ, Rio de Janeiro, v. 33, n. 24, p. 92-104, 2011.

CICCONE, A. L'archaique et l'infantile. In: Spirale. Eres, v.45, p. 133-147, 2008. Disponível em: https://www.cairn.info/revue-spirale-2008-1-page-133.htm\# . A ritmicidade nas experiências do bebê, sua segurança interna e sua abertura para o mundo. In: Continuidade e descontinuidade no processo de subjetivação do bebê. São Paulo: Escuta, 2018. p. 15-28.

DAADORIAN, D. Permanência e constância dos pais no tratamento psicanalítico da criança. In: Continuidade e descontinuidade no processo de subjetivação do bebê. São Paulo: Escuta, 2018. p. 109-121.

DIAS, E. O. A teoria do amadurecimento de D. W. Winnicott. Rio de Janeiro: Imago, 2003.

FIGUEIREDO, L. C. A metapsicologia do cuidado. In: Psyche. São Paulo, v11, n21, $2007 . \quad$ Disponível em: http://pepsic.bvsalud.org/scielo.php?script=sci_arttext\&pid=S1415$\underline{11382007000200002}$ 
FREUD, S. (1908). Escritores criativos e devaneios. Edição Standard Brasileira das Obras Psicológicas Completas de Sigmund Freud (Vol. IX). Rio de Janeiro: Imago, 2006.

GOLSE, B. (2003). Sobre a psicoterapia pais-bebê: narratividade, filiação e transmissão. São Paulo: Casa do Psicólogo.

GUERRA, V. Formas de (de)subjetivação infantil em tempos de aceleração: os transtornos da subjetivação arcaica. In: Continuidade e descontinuidade no processo de subjetivação do bebê. São Paulo: Escuta, 2018. p. 165-191.

KONICHECKIS, A. Subjetivação e sensorialidade: os embriões do sentido. In: Continuidade e descontinuidade no processo de subjetivação do bebê. São Paulo: Escuta, 2018. p. 75-94.

MACHADO, M. M. O brinquedo-sucata e a criança: a importância do brincar. Atividades e materiais. São Paulo: Edições Loyola, 2010.

MALDONADO, M. T. Psicologia da gravidez: parto e puerpério. Petrópolis, Editora Vozes, 1985.

MILMAN, L. Um pouco de história. In: A Casa da Árvore: uma experiência inovadora na atenção à infância. Rio de Janeiro: Garamond, 2008. p. 31-51.

ROUSSILLON, R. Paradoxos e situações limite da psicanálise. Rio Grande do Sul: Unisinos, 2006.

(2004). La dépendance primitive et l'homosexualité primaire «en double». Revue française de psychanalyse 2004/2, 68, 421-439. Disponível em: 10.3917/rfp.682.0421

SABOYA, A. S. L.; ANDRIETO, E. Mães psicóticas e seus bebês: uma leitura winnicottiana. In: Arquivo Brasileiros de Psicologia, v. 61, n. 3, Rio de Janeiro, dez., $2009 . \quad$ Disponível em: http://pepsic.bvsalud.org/scielo.php?script=sci_arttext\&pid=S1809$\underline{52672009000300011}$

SAFRA, G. Desvelando a memória do humano: $O$ brincar, o narrar, o corpo, o sagrado, o silêncio. São Paulo: Edições Sobornost, 2006. 
WINNICOTT, D. W. (1942). Por que as crianças brincam? In: A criança e seu mundo. Rio de Janeiro: Guanabara-Koogan, 1982.

Os bebês e suas mães. São Paulo: Martins Fontes, 1987. . (1978). Preocupação materna primária. In D. W. Winnicott, Da pediatria à psicanálise (p.491-499). Rio de Janeiro: Francisco Alves. (Trabalho original publicado em 1956)

. (1974) O medo do colapso. In Explorações psicanalíticas. Porto Alegre: Artes Médicas.

(1975). Objetos e fenômenos transicionais. In: O brincar e a realidade. Rio de Janeiro: Imago. p. 13-44. (Originalmente publicado em 1951). . (1975) O brincar: uma exposição teórica. In: O brincar e a realidade. Rio de Janeiro: Imago. p. 59-77.

(1975) O brincar: atividade criativa e a busca do Eu (Self). In: O brincar e a realidade. Rio de Janeiro: Imago. p. 79-93.

. (1975) A criatividade e suas origens. In: O brincar e a realidade. Rio de Janeiro: Imago. p. 95-120. (1975). A localização da experiência cultural. In: O brincar e a realidade. Rio de Janeiro: Imago. p. 133-142.

. (1975). O lugar em que vivemos. In: O brincar e a realidade. Rio de Janeiro: Imago. p. 145-152. (Originalmente publicado em 1971).

(1975). O uso de um objeto e relacionamento através de identificações. In: O brincar e a realidade. Rio de Janeiro: Imago. p. 121-131. (Originalmente publicado em 1969).

. (1975) O papel de espelho da mãe e da família no desenvolvimento infantil. In: O brincar e a realidade. Rio de Janeiro: Imago. p. 153-162. (Originalmente publicado em 1967).

. (1979). O desenvolvimento da capacidade de se preocupar. In: O ambiente e os processos de maturação. Porto Alegre: Artes Médicas. p. 70- 78. (Originalmente publicado em 1963). 
(1979). A capacidade de estar só. In: O ambiente e os processos de maturação. Porto Alegre: Artes Médicas. p. 70- 78. (Originalmente publicado em 1958).

(1965). O primeiro ano de vida. Concepções modernas do desenvolvimento emocional. In: A família e o desenvolvimento individual. São Paulo:_Martins Fontes, 2011. pp 03-20. (Originalmente publicado em 1963).

. (1965). O relacionamento inicial entre uma mãe e seu bebê. Concepções modernas do desenvolvimento emocional. In: A família e o desenvolvimento individual. São Paulo: Martins Fontes, 2011. pp. 21-28. (Originalmente publicado em 1963).

. (1965). Fatores de integração e desintegração na vida familiar. In: A família e o desenvolvimento individual. São Paulo:_Martins Fontes, 2011. pp. 5972. (Originalmente publicado em 1963). (1965). A família afetada pela patologia depressiva de um ou ambos os pais. In: A família e o desenvolvimento individual. São Paulo:_Martins Fontes, 2011. pp. 73-88. (Originalmente publicado em 1963).

. (1965). Consequências da psicose parental para o desenvolvimento emocional da criança. In: A família e o desenvolvimento individual. São Paulo: Martins Fontes, 2011. pp. 101-114. (Originalmente publicado em 1963).

ZORNIG, S. A.; GABEIRA, T. R. Os eixos do cuidado na primeira infância. In: Cadernos de Psicanálise, CPRJ, Rio de Janeiro, v. 35, n. 29, p. 143-158, jul./dez. 2013. Disponível em: http://pepsic.bvsalud.org/pdf/cadpsi/v35n29/a09.pdf ZORNIG, S. A. A criança e o infantil em psicanálise. São Paulo: Escuta, 2008. Transferência na clínica psicanalítica com crianças. Jornal de Psicanálise, São Paulo , v. 41, n. 75, p. 123-133, dez. 2008. Disponível em: http://pepsic.bvsalud.org/scielo.php?script=sci_arttext\&pid=S0103$\underline{58352008000200009}$

Clínica dos primórdios e processos de simbolização primários. Psicol. clin., Rio de Janeiro, v. 27, n. 2, p. 121-136, 2015 . Disponível em: 
Continuidade e descontinuidade no exercício da parentalidade. In:

Continuidade e descontinuidade no processo de subjetivação do bebê. São Paulo: Escuta, 2018. p. 95-107.

Reflexões sobre uma ética do cuidado na primeira infância. In:

Primórdios: psicanálise aplicada: diferentes formas de cuidar, Rio de Janeiro: CPRJ, v. 1 n. 1, p. 15-26, 2010. Disponível: http://cprj.com.br/primordios/1526_reflexoes.pdf 